Wes 1849

Policy Research Working Paper 1849

\section{Regional Integration and Factor Income Taxation}

Valeria De Bonis

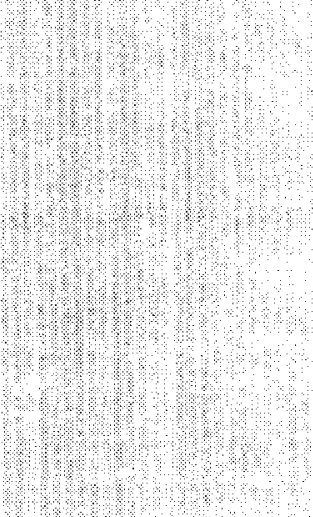

Even if concerted agreements might help reduce inefficiencies resulting from regional differences in income tax making regional taxes Uniform may not be the best solution to the problem but imposing a minimum tax rate could be.

The World Bank Development Research Group November 1997 


\section{Summary findings}

De Bonis analyzes (both theoretically and empirically) the international distortions and fiscal interdependence that arise because of different tax rates among a region's countries.

She also studies what happens when the countries try to harmonize taxes, focusing on how the countries' size influences results, how strategic behavior changes under different international tax rules, and what happens to relationships with countries excluded from the integration process.

Among her findings:

- In the case of highly mobile factors, such as financial capital, competition involves the risk of tax rates and revenues being brought down to extremely low levels, so some form of concerted agreement seems necessary, although cooperation need not involve tax rate uniformity. But regional agreements might be ineffective when factors can move to the rest of the world.

- In the case of less mobile factors, such as physical capital, competition would not yield the outcome of extremely low tax rates. Then the need for concerted international intervention is weaker. But international coordination in the form of imposing a minimum tax rate might be beneficial in some cases.

- As for taxing foreign direct investment in developing countries, in the context of regional NorthSouth integration agreements, it is possible that differences in the countries' objective functions eliminate the incentive for strategic reactions. In the context of South-South agreements, incentives for the integrating, capital-importing countries to compete with each other are determined by the kind of tax system chosen in the capital-exporting rest of the world. In the case of exemption, competition would drive capital income tax rates down. In the case of a credit system, competition would take place only in tariffs (or other trade taxes). What is required then is an agreement not on capital income taxes but on a common external tariff.

- In the presence of migration costs or a link between the tax rates on mobile and immobile factors, the absence of coordination does not lead to a zero tax rate on mobile factors. Both countries' welfare can be improved by imposing a minimum tax rate, but not a uniform tax rate.

This paper - a product of the Development Research Group - is part of background work for the group's program on regionalism and development. Copies of the paper are available free from the World Bank, $1818 \mathrm{HStreet}$ NW, Washington, DC 20433. Please contact Jennifer Ngaine, room N5-060, telephone 202-473-7947, fax 202-522-1159, Internet address trade@worldbank.org. November 1997. (54 pages)

The Policy Research Working Paper Series disseminates the findings of work in progress to encourage the exchange of ideas about development issues. An objective of the series is to get the findings out quickly, even if the presentations are less than fully polished. The papers carry the names of the authors and should be cited accordingly. The findings, interpretations, and conclusions expressed in this paper are entirely those of the authors. They do not necessarily represent the view of the World Bank, its Executive Directors, or the countries they represent. 


\title{
REGIONAL INTEGRATION AND FACTOR INCOME TAXATION
}

\author{
Valeria De Bonis $\left({ }^{*}\right)$
}

$\left.{ }^{*}\right)$ This paper was written mainly during a stay in the International Trade Division, World Bank, in Summer 1996, and is part of the background work for the Division's program on Regionalism and Development. I thank Alan Winters and Maurice Schiff for helpful comments and suggestions. 



\section{Foreword}

As regional trading arrangements (RTAs) have spread, enlarged and deepened over the last decade, they have posed challenges to economists on both intellectual and policy levels. On the former, do RTAs stimulate growth and investment, facilitate technology transfer, shift comparative advantage towards high value-added activities, provide credibility to reform programs, or induce political stability and cooperation? Or do they, on the other hand, divert trade in inefficient directions and undermine the multilateral trading system?

The answer is probably "all of these things, in different proportions according to the particular circumstances of each RTA." This then poses the policy challenge of how best to manage RTAs in order to get the best balance of benefits and costs. For example, should technical standards be harmonized and, if so, how; do direct or indirect taxes need to be equalized; how should RTAs manage their international trade policies in an outward-looking fashion?

Addressing these issues is one important focus of the international trade research program of the Development Research Group of the World Bank. It has produced a number of methodological innovations in the traditional area of trade effects of RTAs and tackled four new areas of research: the dynamics of regionalism (e.g., convergence, growth, investment, industrial location and migration), deep integration (standards, tax harmonization), regionalism and the rest of the world (including its effects on the multilateral trading system), and certain political economy dimensions of regionalism (e.g., credibility and the use of RTAs as tools of diplomacy).

In addition to thematic work, the program includes a number of studies of specific regional arrangements, conducted in collaboration with the Regional Vice Presidencies of the Bank. Several EU-Mediterranean Association Agreements have been studied and a joint program with the staff of the Latin American and Caribbean Region entitled "Making the Most of Mercosur" is under way. Future work is planned on African and Asian regional integration schemes.

Regionalism and Development findings have been and will, in future, be released in a number of outlets. Recent World Bank Policy Research Working Papers concerning these issues include:

Glenn Harrison, Tom Rutherford and David Tarr, "Economic Implications for Turkey of a Customs Union with the European Union," (WPS 1599, May 1996).

Maurice Schiff, "Small is Beautiful, Preferential Trade Agreements and the Impact of Country Size, Market Share, Efficiency and Trade Policy," (WPS 1668, October 1996).

L. Alan Winters, "Regionalism versus Multilateralism," (WPS 1687, November 1996). Magnus Blomström and Ari Kokko, "How Foreign Investment Affects Host Countries" (WPS1745, March 1997) 
Magnus Blomström and Ari Kokko, "Regional Integration and Foreign Direct

Investment: A Conceptual Framework and Three Cases" (WPS1750, April 1997)

Eric Bond, "Using Tariff Indices to Evaluate Preferential Trading Arrangements: An Application to Chile" (WPS1751, April 1997)

Pier Carlo Padoan, "Technology Accumulation and Diffusion: Is There a Regional Dimension?" (WPS1781, June 1997)

Won Chang and L. Alan Winters, "Regional Integration and the Prices of Imports: An Empirical Investigation" (WPS1782, June 1997)

"Glenn Harrison, Thomas Rutherford and David Tarr, "Trade Policy Options for Chile: A Quantitative Evaluation" (WPS1783, June 1997)

Anthony Venables and Diego Puga, "Trading Arrangements and Industrial Development" (WPS1787, June 1997)

Raquel Fernandez, "Returns to Regionalism: An Evaluation of Nontraditional Gains from Regional Trade Agreements" (WPS1816, August 1997)

Planned future issues in this series include:

Sherry Stephenson, "Standards, Conformity Assessments and Developing Countries"

Valeria De Bonis, " Regional Integration and Commodity Tax Harmonization"

Other papers on regionalism produced by IECIT include:

Ahmed Galal and Bernard Hoekman (eds), Regional Partners in Global Markets: Limits and Possibilities of the Euro-Med Initiative. CEPR 1997.

Bernard Hoekman and Simeon Djankov, "Imports of Inputs, Foreign Investment and Reorientation of East European Trade," World Bank Economic Review (forthcoming)

Bernard Hoekman and Simeon Djankov, "The EU's Mediterranean Free Trade Initiative," World Economy

Bernard Hoekman and Simeon Djankov, "Effective Protection in Jordan and Egypt in the Transition to Free Trade with Europe," World Development.

Bartlomiej Kaminski, "Establishing Economic Foundations for a Viable State of Bosnia and Hercegovina: Issues and Policies". 
In addition, Making the Most of Mercosur issued the following papers:

Alexander J. Yeats, "Does Mercosur's Trade Performance Raise Concerns About the Effects of Regional Trade Arrangements?" (WPS1729, February 1997))

Azita Amjadi and L. Alan Winters, "Transport Costs and 'Natural' Integration in Mercosur" (WPS1742, March 1997)

Claudio Frischtak, Danny M. Leipziger and John F. Normand, "Industrial Policy in Mercosur: Issues and Lessons"

Sam Laird (WTO), "Mercosur Trade Policy: Towards Greater Integration"

Margaret Miller and Jerry Caprio, "Empirical Evidence on the Role of Credit for SME Exports in Mercosur"

Malcom Rowat, "Competition Policy within Mercosur"

For copies of these papers or information about these programs contact Maurice Schiff, The World Bank, 1818 H Street NW, Washington, D.C. 20433.

\author{
L. Alan Winters \\ Research Manager \\ Development Research Group
}




\section{Summary}

This paper analyses the issue of factor income taxation in the context of regional integration agreements. If countries remove the barriers to trade and factor movement, taxation will distort the allocation of resources across borders. Tax uniformity would eliminate this problem. Uniformity can be obtained either through formal agreements (harmonization) or through competition between countries, which have an incentive to reduce taxation on factor income to attract factors. This would create a spillover effect and promote a downward spiraling of the tax rates. In either case, uniformity is not necessarily an optimal outcome. In the case of tax harmonization, the tax rate at which equalization takes place might increase the intra-national misallocation of resources deriving from taxation, since it is difficult to find the efficient system around which to harmonize and this might not be the same for different countries. Also when achieved through tax competition uniformity would disregard countries' differences; tax rate would be lower than in the harmonization solution and inefficient because of the presence of the negative externality. It seems therefore that some form of tax coordination could be useful in improving welfare by internalizing the reciprocal spillover effects of taxation policy. The discussion of the principles of international taxation and the analysis of fiscal policy coordination are the main guidelines of the paper. In particular, the conflict between the criteria of capital export and capital import neutrality is analysed and it is shown that meeting both of them, as obtained with fiscal harmonization, does not necessarily lead to the maximization of global welfare; also, it is stressed that coordination is useful in increasing global welfare only if fiscal policies of different countries are interdependent. In particular, the interdependence can be destroyed by the presence of countries excluded by the cooperation agreement. The findings of the paper suggest that: 1) in the case of highly mobile factors, like financial capital, competition involves the risk of tax rates and revenues being brought down to extremely low levels and therefore some form of concerted agreement appears necessary, though cooperation need not involve tax rate uniformity. However, regional agreements might be ineffective when factors can move to the rest of the world. 2) In the case of less mobile factors, like physical 
capital, competition would not yield the outcome of extremely low tax rates; then, the need for international concerted intervention is less strong; however, international coordination in the form of imposition of a minimum tax rate might be beneficial in some cases. 3) As for taxation of foreign direct investment in developing countries, in the context of regional North-South integration agreements, it is possible that differences in the countries' objective functions eliminate the incentives to strategic reactions; in the context of South-South agreements, the incentives for the integrating, capital importing countries to compete with each other are determined by the kind of taxation system chosen in the capital-exporting rest-of-the-world; in the case of exemption, competition would drive capital income tax rates down; in the case of a credit system, competition would take place only in the field of tariffs (or other trade taxes) and what is required, then, is not an agreement on capital income taxation, but on a common external tariff. 4) Finally, the appendix of the paper formally analyses the effects of factor income taxation and of the negative externality of the tax rate setting game in the presence of factor mobility in a two-country model. It shows that, in the presence of migration costs or of a link between the tax rate on mobile and immobile factors, the absence of coordination does not lead to a zero tax rate on mobile factors. It is also argued that both countries' welfare can be improved by the imposition of a minimum tax rate, but not of a uniform one. 


\section{Contents}

I. Introduction

II. Taxation and factor movement

III. Capital income taxation (financial investment)

1. Basic principles of international direct taxation

2. Taxation and efficiency

3. Avoiding double taxation

4. National and global welfare maximization

5. National and global welfare in the case of fiscal interdependence

a. Strategic behavior and coordination with the credit and deduction methods

b. Strategic behavior and coordination with the residence and source principles

c. Coordination and third countries

6. Empirical relevance of the effects of tax harmonization

IV. Capital income taxation (foreign direct investment)

1. Taxation and distortions

a. Theoretical background

b. Empirical evidence

2. Distortions and competition

a. Theoretical background

b. Competition in practice

3. Tax coordination and developing countries

a. Principles of tax coordination

b. Institutional arrangements

c. Competiton to atract foreign direct investment

V. Conclusions and directions for further research

Appendix

Bibliography 


\section{Introduction}

All over the world, countries engage in regional integration. One of the driving forces behind this development has been the economic benefits associated with regional integration: liberalizing goods and factor movements, harmonizing technological standards, and cooperation in economic policies are generally thought to enhance efficiency and thereby foster economic development and global welfare. One of the questions that has arisen in this context is to what degree fiscal systems comprising tax structure, tax rates, treatment of foreign income, deductibility of foreign-paid taxes, etc. - need to be harmonized to enjoy the full benefits of regional integration. This concerns both trade in goods and services, factor movement, as well as foreign direct investment. What makes such issues relevant in the case of regional integration is the existence of distortions or external effects deriving from taxation. Relevant questions include: Is harmonization of indirect taxes necessary in a regional trade arrangement to avoid fiscal distortions? Which country should have the right to tax income from factors that cross international borders? Does foreign direct investment depend to a significant extent upon harmonization of its fiscal treatment? What is the impact of regional fiscal arrangements on countries left outside of the agreement?

This paper concentrates on issues of factor income taxation. The taxation problems dealt with here derive from the fact that lump-sum instruments are generally not available; therefore, taxation distorts the allocation of resources. If countries are open and their tax structures differ, there will be a misallocation of mobile resources across borders. Uniformity of the national tax systems would, of course, eliminate the "international" distortion. Uniformity can be obtained via harmonization, i.e. a concerted equalization of tax structures through formal agreements, or competition between fiscal systems, which tends to lower rates because each country has an incentive to reduce taxation on factor income in order to attract factors within its borders. In fact, in the case of perfectly mobile factors, it is argued that rates would be equalized at the zero level. 
But is uniformity an optimal outcome? In the case of harmonization, equalization of tax rates certainly eliminates international distortions, but the tax rate at which equalization takes place might be an inefficient one, in the sense that intranational misallocations of resources increase. This can happen because, first, it is difficult to know the "right" system around which to harmonize (Tanzi and Bovenberg, 1990); second, the efficient tax system is not necessarily the same for all countries. In fact, uniformity does not allow for the respect of differences in countries' preferences, which involves further costs. In general terms, taxation is used to finance public expenditure and different countries might have different public expenditure needs and different available instruments to finance them. For instance, there might be different preferences for public goods across countries; or the mix of the private and public sectors can be different. In principle, then, countries might be worse off as a result of harmonization. By the same reasoning, uniformity achieved through competition would also disregard differences in countries' preferences - the difference being that tax rates would be set at lower levels than in the case of harmonization. In fact, in the case of competition, losses deriving from taxation within each country would decrease since tax rates are brought down. Tax rates might go down too much, however, because of international spillover effects that countries do not internalize when setting the tax rates strategically. ${ }^{1}$ It seems therefore that system competition cannot lead to an optimal outcome either.

Some concerted international measure appears necessary; however, rather than being inspired by the principle of uniformity, it could follow that of coordination, in the sense of internalizing the reciprocal spillover effects of taxation policies. In other words, this means not exploiting the partner countries and a mutual recognition of taxation powers. ${ }^{2}$ However, coordination at the regional level still leaves externalities

\footnotetext{
1 These externalities derive from the fact that even a government that maximizes its own citizens' welfare can enforce measures that affect the utility of the citizens of a different country. Since the utility of foreigners is not taken into account when governments decide on taxation, externalities arise. For a description and a formal treatment of these external effects see Gordon (1983).

2 The problem of eliminating the international externalities can be tackled by comparing it with the problem of eliminating externalities between individuals. There are three standard solutions. Externalities would of course not exist in the interpersonal setting if those who produce the externality, on the one hand, and those who suffer or benefit from it, on the other hand, were the same people. In
} 
to and from the outside countries, which must be taken into account when looking at the efficacy of the coordination measures undertaken by the integrating countries.

Against this background, the paper addresses the following theoretical and empirical issues: the effects of factor mobility on countries undergoing economic integration (section II); capital income taxation and the maximization of national and global welfare (section III); the kind of regional fiscal agreements needed for foreign direct investment taxation (section IV). Section $\mathrm{V}$ draws the conclusions of the analysis and suggests topics for empirical research. The appendix presents a formal treatment of competition when factors have different degrees of mobility.

\section{Taxation and factor movement}

This section briefly analyzes two general problems which arise in the context of regional agreements. The first question is whether factor mobility is required in addition to free trade in order to obtain the benefits of integration. The second question is whether factor mobility decreases the efficacy of redistributive government policies.

the international settings externalities could be avoided by enlarging the tax jurisdiction. Another solution to interindividual externalities is that provided by Pigouvian taxes or subsidies. The corresponding measure at the international level could be that of preserving national decision making, but at the same time allowing for a system of revenue sharing and matching grants (how to construct such a system is still an open question). A third solution is that of establishing "property rights" (Coase, 1960 ), in this case on the tax base. The first solution corresponds to eliminating the externalities through thr assignment of the right to tax to a supranational entity, which would then presumably apply a unique tax in its whole jurisdiction. Uniformity, however, brings about the problems already mentioned (let alone the political difficulties of giving up national sovereignty). The experience of existing federal states suggests that there are many possible degrees of fiscal integration, not necessarily leading to full harmonization. The latter two forms of eliminating the externalities can instead be considered as forms of coordination, in which the concept of uniformity is abandoned for that of mutual recognition and the establishment of transnational rules. Coordination might allow for retaining the maximum flexibility compatible with the removal of tax obstacles to economic integration. Therefore a basic principle of tax coordination should be that of neutralizing as many cross border externalities as possible. 
Factor mobility is not always required to obtain the full benefits of integration. From the factor price equalization theorem of the Heckscher-Ohlin model it is well known that factor prices will be equalized by trade in goods alone - provided that factor endowments are sufficiently similar to prevent full specialization in production - so that free trade gives a first-best solution. In a world with two factors, capital and labour, if their proportions differ by too much to prevent specialization in production, then mobility of only one factor (e.g. capital) will suffice to ensure factor price equalization and the first best allocation of resources. There is no need for mobility of the other factor (e.g., labor). This conclusion, however, does not hold if there are economies of scale or intermediate inputs in production.

There are other examples where factor movement is required to reach the full benefits of integration. In general, factor movement is required when some situation prevents trade from equalizing factor prices (see Mundell, 1957, and Markusen, 1983, for some examples).

Whether factor movement is necessary or not to obtain the full benefits of integration, if integration takes place, the pressing question becomes whether income taxes should be harmonized in the integrating countries. The remainder of the paper will concentrate on efficiency questions connected to capital movements, which are considered to be the most mobile among production factors. Before that, however, some distributional implications of factor mobility should be mentioned.

In general, freedom of movement facilitates more efficient allocation of factors. Migration, however, changes the distribution of income among immobile and mobile factor owners (see Wildasin, 1994).

In a risky environment, mobility also affects the distribution of the income risk. Mobility decreases the risk of the mobile factor if income at home is uncertain while being certain abroad, shifting the risk to the immobile factor (Wildasin, 1995a and 1995b). 
There are other aspects of the connection between integration and government redistributive policies. In the presence of redistributive transfers from owners of the immobile to those of the mobile factor, it may be Pareto improving for the immigration region to make transfers to mobile workers of the emigration one to limit immigration to some maximum level (Wellisch and Wildasin, 1996; compare with Schiff, 1994, for cases of complementarity between foreign aid and migration).

One last problem deriving from fiscal interdependence is that, if factors of production are footloose, tax rates will be governed by the rates prevailing abroad. However, costs of factor mobility may provide some scope for tax differentials between jurisdictions; moreover, governments may be able to sustain higher levels of taxation without eroding the tax base if those who bear the tax burden benefit from public expenditure.

\section{Capital income taxation (financial investment)}

This section analyses the effects of taxation of international capital flows in order to draw conclusions on the need for tax harmonization at the regional level. It first looks at the global efficiency implications of taxation to find a theoretical rationale for harmonization. Second, it contrasts the harmonization outcome with the results of the choices that countries make when maximizing national welfare. Then, it considers the possibility and consequences of strategic behavior. Finally, some empirical evidence on the sensitivity of portfolio choices to international tax rate differentials is presented.

\section{Basic principles of international direct taxation}

When factors and factor returns cross international borders, the problem of which country has the right of taxing them arises. Two polar principles constitute the common basis of international taxation: the residence principle and the source principle. Under the residence principle, the residence of the tax payer is the basis for 
assessing tax liabilities: a country will then tax its residents uniformly for their worldwide income, irrespective of the country where it has been earned; non residents are not taxed for income earned in the country. Under the source principle, the location where income originates (the location of investment, as for capital income) is the basis for assessing tax liabilities; therefore, a country levies the tax on income originating within its borders, irrespective of the residence of the tax payer. Residents are not taxed for income earned abroad. Application of the residence principle is consistent with the goal of horizontal equity, according to which all incomes accruing to an individual should be taxed in the same way: the residence principle allows for the taxation of foreign source income within the personal income tax. Taxation on the basis of the source principle may be justified as a charge for the use of resources of the country where the investment is taking place. The choice between the two principles matters. For instance, capital importing countries (e.g. developing countries) would do better under the source rule, while capital exporters would benefit from the residence one. In terms of regional equity, however, one cannot say which principle should prevail. The choice between the two principles also entails different efficiency implications, as explained below.

\section{Taxation and efficiency}

In a closed economy, capital income taxation drives a wedge between the marginal productivity of capital and the return to the person who is financing it. This return is the after tax rate of interest, which equals the marginal rate of substitution between present and future consumption in equilibrium. In an open economy, differential taxation induces at least one of two additional distortions ${ }^{3}$ : cross country differences in intertemporal rates of substitution (under the residence principle), which cause an inefficient allocation of world savings, and cross country differences in marginal productivity of capital (under the source principle), which cause an inefficient allocation of the world capital stock.

${ }^{3}$ For this analysis see, for instance, Frenkel, Razin and Sadka (1991). 
Cross country differences in intertemporal marginal rates of substitution arise if taxes are levied according to the residence principle at different tax rates in different countries. To see why, consider that savers in each country equate their marginal rate of substitution to the after tax interest rate. Since the residence principle implies that the tax rate is the same irrespective of the location of investment, the before tax returns must also be the same in equilibrium. This means that the marginal productivity of capital will be the same in all countries. However, if countries apply different tax rates, the net returns to savers will diverge across countries and the international allocation of savings will be distorted. In other words, application of the residence principle yields: an efficient allocation of the world capital stock; for savers within a country, indifference between channeling savings to the home country or abroad, since the after tax rates of return are equalized (this condition goes under the name of capital export neutrality, or CEN); and an inefficient allocation of world savings. Residence based taxes are essentially taxes on savings. To avoid them, people could in principle move their residence to countries where taxes are lower, and this might induce competition between countries, which are pushed to lower tax rates in order to attract (or not to lose) tax base ${ }^{4}$.

Cross country differences in the marginal productivity of capital will instead arise if taxes are levied according to the source principle at different rates across countries. In this case, within each country the same return will be earned irrespective of the investor's country of residence. Since in equilibrium economic agents must earn the same return wherever they are channeling savings, the same net return will be earned by residents of all countries. This means that the intertemporal marginal rates of substitution are equal across countries. However, if tax rates differ, the before tax interest rates will differ, i.e. the marginal productivity of capital will diverge from country to country. Thus, the international allocation of the world stock of capital will be inefficient. Therefore, application of the source principle at different rates across countries implies: an efficient allocation of world savings; the same treatment to

\footnotetext{
${ }^{4}$ Migration could lead to decentralized Tiebout types of equilibria and make coordination superfluous. There is a vast literature, however, showing that this applies only to particular circumstances (see for instance Bewley, 1982; Gordon, 1983).
} 
investors in the country irrespective of their residence (this condition is called capital income neutrality, or CIN); and an inefficient allocation of the world capital stock. Source based taxes are essentially taxes on investment. Therefore, there is an incentive to reallocate capital toward countries where taxes are lower.

An efficient allocation of both savings and investment, as well as CEN, and $\mathrm{CIN}$ are obtained if either taxation principle is adopted but the same tax rate is chosen in all countries. Elimination of distortions is therefore the theoretical rationale for capital income tax harmonization. Of course, if harmonization takes place only in the context of a regional integration process, with tax differentials being abolished between a group of countries (the union), but maintained with the rest of the world, equalities between the marginal rate of intertemporal substitution and the marginal productivity of capital will not apply at the global level. Even if it does not ensure global efficiency, there is still a rationale for harmonization at the regional level, since this provides neutrality within the union. This is particularly important for countries which have high economic and financial integration, since the removal of barriers to factor movements exposes resource allocation more directly to tax rate differentials. The deeper economic integration is, the stronger becomes the rationale for tax harmonization. The regional dimension of tax harmonization is thus a consequence of the regional dimension of economic integration.

\section{Avoiding double taxation}

Of course, when both the capital exporting and the capital importing country raise taxes and adopt mixtures of the origin and residence principles, double taxation of the same income may arise. This is usually eliminated by systems of tax credits or tax deductions. To begin with, consider a world formed by two countries, home and foreign (where foreign values are denoted by an asterisk, $\left.{ }^{*}\right)$. Call $t_{\mathrm{rd}}\left(\mathrm{t}_{\mathrm{rd}}{ }_{\mathrm{rd}}\right)$ the tax rate levied on residents on their domestic source income; $t_{\mathrm{rf}}\left(\mathrm{t}_{\mathrm{rf}}{ }_{\mathrm{r}}\right)$ the tax levied on 
residents on their foreign source income; $\mathrm{t}_{\mathrm{nd}}\left(\mathrm{t}_{\mathrm{nd}}\right)$ the tax levied on non residents on domestic source income. Suppose that the home country adopts the residence principle and the foreign country the source principle. When the source country offers a tax credit, the tax paid abroad is deducted from the tax liability in the home country5. A deduction, instead, means that taxes paid to the foreign country are subtracted from income before assessing the tax liability. Therefore, a deduction offers a smaller relief from double taxation than a credit. Table I summarizes methods aimed at avoiding double taxation (see also Findlay, 1988).

Table I.

Avoiding double taxation

\begin{tabular}{|c|c|c|}
\hline & Tax revenue for $f$ & Tax revenue for $h$ \\
\hline 1 Exemption in $h$ & $t^{*}{ }_{n d}$ & - \\
\hline 2 Exemption in $f$ & - & $t_{r f}$ \\
\hline 3 Ordinary credit & $t^{*}$ nd & $t_{r f}-\min \left(t_{r f} ; t^{*}{ }_{n d}\right)$ \\
\hline 4 Integral credit & $t^{*}{ }_{n d}$ & $\mathbf{t}_{\mathrm{rf}} \mathbf{t}^{*}{ }_{\mathrm{nd}}$ \\
\hline 5 Deduction & $t^{*}{ }_{n d}$ & $t_{r f f}\left(1-t^{*}{ }_{n d}\right)$ \\
\hline
\end{tabular}

Notation: $t$ stands for the tax on one unit of return; $h$ stands for the home (capital exporting) country; f stands for the foreign (capital importing) country.

Note that exemption in the residence country or credit are the methods included in the OECD Model tax treaty.

\footnotetext{
${ }^{5}$ Credit can be partial or full according to whether it covers the whole foreign source tax payment or only a fraction of it; usually, if the foreign tax rate is higher than the home one, a resident of the home country does not receive a refund for the excess foreign tax.
} 


\section{National and global welfare maximization}

Application of either the residence or the source principle by all countries will eliminate international distortions under tax rate harmonization. Even without tax rate uniformity, double taxation would be avoided and either CEN or CIN would be obtained. The question to address at this point is whether a country trying to maximize its own welfare would choose one of these principles. The answer is no. Corden (1967) and Findlay (1986) show that the interest of the exporting (importing) country is to tax less income from exported (imported) capital than income from domestically invested capital ${ }^{6}$. This is incompatible with both criteria of international

${ }^{6}$ To see this, consider first the situation of a small capital importing country. Small means that it has no market power; capital importing means that its demand for capital and its domestic supply of capital yield an equilibrium corresponding to a level of the interest rate which is above the world one. Import of capital then raises domestic welfare since the stock of domestically invested capital increases and cheaper foreign capital replaces the domestic one. Assume that the country is trying to raise a certain amount of revenue at a minimum deadweight loss; the only tax base is income from capital and two tax rates can be chosen: that on income from capital owned by residents $\left(t_{r d}\right)$ and that on income from capital invested at home but owned by non residents $\left(t_{n d}\right)$. If the country taxes only income from capital owned by residents, this tax would create a distortion by reducing the domestic supply and therefore the stock of domestically owned capital. However, the decrease in the stock owned by residents would be matched by an inflow of (untaxed) foreign capital and there would therefore be no distortion of the size of the total stock of capital. There would however be a welfare loss from the replacement of domestic with foreign capital which can be interpreted as a reduction of the surplus of the country as a capital producer. If the tax is then imposed on imported capital income, the size of the total stock of capital goes down, which is a second distortion. Also, cheaper foreign capital is replaced by more expensive domestic one (this, however, reduces the first distortion). The country suffers a welfare loss which can be interpreted as a decrease in its surplus as a consumer of capital. The size of the first distortion is related to the difference between the tax rate on domestically owned capital and that on foreign owned capital $\left(t_{r_{d}}-t_{n d}\right)$. Which is the optimal relationship between the two rates? To answer this, it is useful to look at some special cases. If the supply curve of domestic capital is perfectly inelastic, all revenue can be raised by taxing domestically owned capital income, and exempting foreign owned capital income. This is because domestic supply will not change in this case and there will be no welfare loss of the country as a producer of capital (producer surplus is zero in the case of perfectly inelastic supply). If instead the demand for capital is perfectly inelastic, revenue can be raised by taxing at the same rate income from the domestically owned and the foreign owned capital stocks (since there can be no decrease in consumer surplus which is zero in this situation). The general case will be between these two extremes, with $t_{r d}>t_{n d}$. The reverse reasoning can be made for the capital exporting country. Briefly, a tax on income from exported capital $\left(\mathrm{t}_{\mathrm{rf}}{ }_{\mathrm{f}}\right)$ only will reduce the country producer surplus, since capital supply will decrease and some capital invested abroad will be relocated at home, where it earns a lower return. A tax on income from capital invested domestically $\left({ }^{*}{ }^{*}\right.$ rd $)$ would cause a reduction in the country's consumer surplus, since capital would be relocated abroad. This would not happen with $\mathrm{t}_{\mathrm{rd}}=\mathrm{t}_{\mathrm{rf}}^{*}$. Then, the welfare loss due to the reduction in the consumer surplus would be eliminated; however, the domestic supply of capital is reduced and there will be a loss due to a reduction in the producer surplus. With $t^{*}{ }_{r f}=0$ and $t_{r d}>0$, there will be no loss in producer surplus, 
efficiency. One also must consider, however, the case of mixed portfolios, i.e. of a country which is both a capital importer and a capital exporter. Then, arbitrage possibilities imply that in equilibrium economic agents are indifferent between investing at home or abroad:

$$
\begin{aligned}
& r\left(1-t_{r d}\right)=r^{*}\left(1-t^{*}{ }_{n d}-t_{r f}\right) \quad \text { (for the residents of the home country) } \\
& r\left(1-t_{n d}-t_{r f}\right)=r^{*}\left(1-t_{r d}^{*}\right) \quad(\text { for the residents of the foreign }
\end{aligned}
$$
country) ${ }^{7}$

If these equalities were violated, unlimited profits could be gained by borrowing in the low (net of tax) interest rate country to invest in the high (net of tax) interest rate one. For positive values of $r$ and $r^{*},(1)$ and (2) imply:

$$
\left(1-t_{r d}\right)\left(1-t_{r d}^{*}\right)=\left(1-t^{*}{ }_{n d}-t_{r f}\right)\left(1-t_{n d}-t_{r f}\right)
$$

This condition is compatible with residence and source taxation, but also with various combinations of $t_{r d}, t_{n d}, t^{*}{ }_{r d}$ and $t^{*}{ }_{n d}$. Therefore, not even the arbitrage possibilities will push a country to adopt one of the neutrality criteria.

Which taxation system will a country then choose? Consider the case of the exporting country taking taxes levied by the importing country as given. The exporting country fixes the tax rates to optimize the allocation of capital domestically offered and takes arbitrage possibilities into account. Feldstein and Hartman (1979) and Findlay (1986) show that the optimal rule is then the "full tax after deduction" (i.e. source tax on exported capital is deductible from the tax base, and $t_{\mathrm{rd}}=t_{\mathrm{rf}}$, i.e. there is no discrimination between internally and externally invested capital). This rule achieves the so called "national efficiency" (NE): the marginal revenue of capital invested abroad, net of foreign taxes (which are a cost for the country), equals the

but the consumer surplus loss will be maximized. Therefore, if domestic demand for capital is perfectly inelastic, it will be optimal to set $t^{*}{ }_{r d}=t^{*}$ rf . In the general case, the optimal solution will involve $t_{r d}^{*}>$ $\mathrm{t}^{*}{ }_{\mathrm{rf}}>0$.

7 See Frenkel, Razin and Sadka (1991). 
marginal revenue of capital invested at home (this is the gross revenue, since home taxes are not a cost for the home country).

Though the full taxation after deduction rule is optimal for the exporting country, it is not optimal at the global level. In fact, it results in a partial double taxation of transborder capital income and is in contrast with both CEN and CIN. Moreover, as shown in Bond and Samuelson (1989), it results in a reduction of international capital movements with respect to a "tax free" situation. 8

To sum up, maximization of national welfare will not lead a country to adopt a taxation rule compatible with either neutrality criteria. Therefore, harmonization through formal agreements seems necessary. However, one can show that uniform tax rates are not necessarily an optimal solution and that, even if some form of coordination of national tax policies would be beneficial, this need not entail uniformity. This issue is addressed in the next section.

\section{National and global welfare in the case of fiscal interdependence}

The analysis has so far abstracted from the fact that the choice of the tax rate made by one country can affect the choice of the other countries. In other words, there is fiscal interdependence and countries may choose to engage in strategic behavior. This complicates the analysis of the relationship between global and national welfare.

${ }^{8}$ There are however cases in which national and global welfare are not in contrast. Horst (1980) shows that some common rules of taxation of income from international investment emerge in cases of particular conditions of capital supply and demand. While he argues that these rules should be adopted through international arrangements, in fact they would be applied also if each country independently maximized its welfare. The first case is that of an inelastic supply in both countries. In this case, savings are insensitive to changes in taxation. Then one needs not fear savings misallocation and the optimal tax is the one that ensures CEN; to obtain this, Horst proposes a system of full credit. However, in the case of perfectly inelastic supply, the capital exporting country would choose $t_{r d}=t_{r f}$, while the capital importing country would choose $t^{*}$ nd $=0$. This rule ensures CEN since it corresponds to the realization of the residence principle. By similar considerations, the second case is that of an inelastic demand in both countries; then, taxation is optimal if CIN is achieved and the source principle applies. The third case is that of an inelastic supply in the capital exporting country and an inelastic demand in the importing country, which leads to the application of the full taxation with deduction rule. The last case is that of an inelastic demand in the capital exporting and an inelastic supply in the capital importing country: exemption of international capital movement should then apply. 


\section{a. Strategic behavior and coordination with the credit and deduction methods}

To introduce the problems connected with strategic behavior, consider again the effects of the "full tax after deduction" rule, i.e. double taxation and failure of obtaining CIN and CEN. What happens if a country autonomously decides to make a choice compatible with the residence principle and CEN and gives a credit for the foreign tax paid? Given that the choice is unilateral, it can cause a strategic response of the foreign country. This may increase the tax rate on imported capital income, $t^{*}{ }_{n d}$, thus increasing revenue, and no allocative effect (i.e. capital flights) will take place, since the tax is reimbursed by the other country (Caves, 1982).

Bond and Samuelson (1989) show how strategic behavior leads to the elimination of trade in capital under the tax credit system. This is because, on the one hand, the capital importing country has an incentive to set the source based tax rate at least as high as the capital exporting country (residence based) tax rate, in order to increase revenue. On the other hand, the capital exporting country tries to set its tax rate above the capital importing one. The authors show that the only Nash equilibrium will then be at tax rates which are so high as to eliminate capital movements. They compare then the credit system to the deduction system (under which some double taxation still remains and the capital importing country does not necessarily try to raise its tax rate at the capital exporting country level) and show that this yields a Nash equilibrium with trade in capital and countries being better off than under the tax credit method. Therefore, credit is not preferable to deduction as in Hamada (1966).

What happens if countries adopt non discriminatory taxation, as might be plausible within some integration agreement? Non discrimination means that the capital exporting country is taxing the capital income of its residents at the same rate, irrespective of whether it is invested at home or abroad $\left(t_{r d}=t_{r f}\right)$; in the same way, the capital importing country is taxing uniformly capital income earned within its borders 
by residents and non residents $\left(t^{*}{ }_{r d}=t^{*}{ }_{n d}\right)$. Under the credit system, the exporting country has an incentive to set $t_{r f}$ (and therefore $t_{r d}$ ) $>t^{*}{ }_{n d}$, in order to raise some revenue. However, increasing the tax rate on capital means reducing its supply. Therefore, there will be some level of $t^{*}{ }_{n d}$ at which the capital exporting country is indifferent between setting $t_{\mathrm{rf}}>t^{*}{ }_{\text {nd }}$ or setting $t_{\mathrm{rf}}\left(=t_{\mathrm{rd}}\right)=0$, i.e. not to tax capital, since the elimination of the distortion in the supply of capital will yield a gain which is equal to that of obtaining higher revenue from the exported capital. Therefore, if $\mathrm{t}^{*}$ nd goes beyond this critical level, the tax rate of the exporting country will go to zero. Then, the capital importing country will reduce its tax rate (since no credit is any longer given). But then, the capital exporting country will again set $t_{\mathrm{rf}}>\mathrm{t}_{\mathrm{nd}}$, and so on. Once again, if the value of $t^{*}$ nd beyond which it is optimal for the home country to put $t_{r f}=0$ is greater than the value of $t^{*}$ nd that the foreign country would choose with $t_{r f}=0$, no Nash equilibrium is reached under the credit method.

The possibility of strategic behavior provides therefore further support to the case for tax arrangements between countries.

\section{b. Strategic behavior and coordination with the residence and source principles}

Similar considerations can be made for the residence and source principles. It can be shown that, when countries independently set their tax rates, Nash equilibria are Pareto inferior to the cooperative ones. This derives from the fact that countries do not take into account the externalities which arise from base usurpation and tax burden export. Reference to two models is useful to illustrate these aspects in the case of large (Sorensen, 1989) and small (Giovannini, 1989) economies. In both models the government is assumed to maximize the utility of a representative individual, with consumption and public expenditures as arguments. Non discrimination between residents and non residents applies.

For the case of large economies, Sorensen (1989) considers two symmetric countries. This means that externalities will have the same sign whatever country 
undertakes the fiscal operation. Therefore, if the externalities are negative (positive) there will be a common interest in reducing (increasing) taxation and coordination will favor both countries. Let us consider separately the cases in which the source and the residence principle apply. Under the source principle, if $t_{n d}$ increases (and therefore so does $t_{r d}$ because of the non discrimination requirement), capital will flow out of the home to the foreign country; the interest rate in the home country increases (because of a partial shifting of the fiscal burden) and that in the foreign country decreases since supply of capital has increased. Given the larger tax base, the foreign country will receive higher revenues (positive externality). A symmetric increase in taxes would benefit both countries. In other words, in the non cooperative case, capital is taxed too little and an increase in taxation would benefit world welfare. Under the residence principle, if $\mathrm{t}_{\mathrm{rf}}$ increases, so must $\mathrm{t}_{\mathrm{rd}}$. Savings in the home country decrease and the interest rate increases. Therefore, capital flows to the home country out of the foreign country, which experiences a decrease in tax base and an increase in interest rate. The foreign country is forced to reduce government expenditure or to increase the taxation of other factors. Given the negative externality, coordination would yield lower tax rates and higher welfare.

For small economies, Giovannini (1989) considers the situation of two small countries where resources are used to purchase domestic capital or foreign assets; the world interest rate is taken as given by the single country. Each country sets its tax rate independently, given that chosen by the other country. While in a cooperative solution the relevant effect of taxation is that of decreasing world savings and investment, independent maximization of national welfare takes other effects into account. If the source principle is applied, the single country will consider that taxing capital invested at home causes capital flight, and will therefore tend to practice a beggar-thy-neighbour policy, decreasing the tax rate in order to attract foreign capital. Since the effect of a change of the tax rates on capital outflow (which is what the country is considering) is greater than that on world savings (which would have been taken into account in a centralized solution), a Nash equilibrium will correspond to an undertaxation of capital income with the underlying distortion. Under the residence principle, the single country does not consider the effect of its taxation on investment, 
which is determined by the world interest rate, and the change in savings due to a tax change is perceived by the single country as a change in foreign assets accumulation. Given that the direction of the response of savings to a change in the world interest rate is ambiguous, the externality could be positive or negative and the Nash solution corresponds either to a too low or too high level of capital taxation.

The results of these two models show that the non cooperative solutions, both with the source and the residence principle, are not optimal. However, there are two cases in which coordination would not be necessary. First, if supply is inelastic in both countries and the residence principle applies, the Nash equilibrium coincides with the cooperative one, since changes in the tax rate do not affect savings. Therefore there is no externality, no fiscal interdependence, and no strategic game. Second, if demand for capital is inelastic and the source principle is applied, taxation will not induce capital flight and once again the non cooperative solution will coincide with the cooperative one. Another case is that of the existence of a third country excluded by the agreements (see section $c$ below). Another result of the models is that, with identical countries, taxation will be uniform both in the cooperative and in the non cooperative equilibrium. However, the former is preferable under welfare considerations. This confirms that equalization of the tax rates is not necessarily an optimal outcome, even if it certainly guarantees CEN and CIN (see also Appendix). One reference in the literature that also supports this is Shaw (1990), where it is shown that harmonization at the average tax rate value can result in a level of investment which is below the optimal one.

\section{c. Coordination and third countries}

In the context of a regional integration process, it is important to consider the influence of third countries, which represent alternative markets with respect to member states. The model in Razin and Sadka (1989), which considers the situation of a small country facing the rest of the world, provides a basis for this analysis. 
Assume that the home and the foreign countries form a community unable of affecting the world interest rate and that at the beginning they do not adopt a common rule on capital income taxation. Each country aims at achieving $\mathrm{NE}$ and is constrained in its taxation choice by the other nation's fiscal instruments and arbitrage possibilities with respect to the rest of the world. Compatibility between the two countries' choices results in

$$
r=r^{w}\left(1-t^{w}\right)=r^{*}\left(1-t^{*}{ }_{n d}\right)
$$

for the home country (where w indicates rest of the world variables); NE is obtained by the full taxation after deduction method. As for the foreign country, symmetrically:

$$
r^{*}=r^{w}\left(1-t^{w}\right)=r\left(1-t_{n d}\right)
$$

which implies:

$$
\begin{aligned}
& r=r^{*} \\
& \left(1-t^{*}{ }_{n d}\right) /\left(1-t_{n d}\right)=1 .
\end{aligned}
$$

This means that gross revenues offered by the union members must be equal and imported capital must be exempted by source taxation, i.e. $t^{*}{ }_{n d}=t_{n d}=0$. This is equivalent to applying the residence principle in its pure form (exemption of non residents income). Therefore, not only NE, but also CEN within the community will be reached: a result of supranational efficiency is obtained as the result of a national welfare maximization process.

Is it possible to increase welfare by coordination? The answer would be yes (as in the models analyzed in section b) if there were fiscal interdependence. Consider then that the crucial variable in the maximization problem is net capital exports. For the home country, next capital exports are the sum of exports toward the foreign country, $\mathrm{S}^{\mathrm{h}}$, and exports toward the rest of the world, $\mathrm{S}^{\mathrm{hw}}$, minus imports from these 
two countries, $\mathrm{S}^{* \mathrm{~h}}$ and $\mathrm{S}^{\mathrm{wh}}$. The level of this variable is a function of the world interest rate, which is given for the home country and for the foreign country. ${ }^{9}$ Then also $S^{\text {wh }}$ increases, which brings $r$ back to its previous level and leaves net exports unaltered.

Therefore the presence of a third country makes the fiscal interdependence between the community members fall and coordination becomes superfluous. The Nash equilibrium is non distortionary, however, since CEN is guaranteed within the community, and is therefore optimal, given the available instruments. This result suggests that in the context of regional integration one should not be too worried about capital income taxation since there is not much one can achieve through it. The other way of looking at this result is that regional tax agreements must be complemented by agreements between the union and the rest of the world.

\section{Empirical relevance of the effects of tax harmonization}

When tax differentials exist among countries, tax systems can only achieve either capital export neutrality or capital import neutrality. As already mentioned, the first one is achieved with residence taxation, which guarantees that the locational choice of investment is not affected by tax considerations, but induces differences in the saving propensities of economic agents in different countries. The reverse applies to source taxation. Then, under the perspective of global welfare maximization, the choice between the residence principle and the source principle should be dictated by the relative magnitude of the degree of intertemporal substitution in consumption (i.e. the interest elasticity of savings) and of international substitutability of investment (i.e., the elasticity of investment with respect to after tax returns).

Most empirical studies on this issue suggest that the elasticity of savings is low (see Smith, 1990) and therefore violations of CIN should involve lower welfare loss than violations of CEN. Then, the residence principle should be preferred. This implies that, if the capital importing country applies a source based tax, the country of residence must grant a credit for the foreign tax paid by the investor. However, if the

\footnotetext{
${ }^{9}$ In fact, if the foreign country increases $t^{*}$ nd, $S^{*}$ decreases and $r$ increases.
} 
effectiveness of tax controls (and tax compliance) remains constrained by national borders, differentials in source tax rates will still affect portfolio compositions, capital allocation among countries, interest yields and tax revenues. Therefore, overcoming these differentials by harmonization of tax rates would involve financial flows among asset categories and countries, with the magnitude of these flows depending on the elasticity of substitution between assets. Even given the lack of empirical estimates of these elasticities, there are indications that they might be quite high. For instance, in October 1987 Germany announced that it would impose a $10 \%$ withholding tax on interest income in 1989. This induced a massive financial capital outflow, certainly eased by the proximity of tax havens like Luxembourg (the tax was removed in the same year of entry into force, 1989, and replaced by a different system in 1993). Similar effects characterized the removal of the $15-20 \%$ withholding tax on non residents undertaken by Canada in 1975 (see Table II).

\section{Table II}

Balance of payments: portfolio investment (bn US \$)

\begin{tabular}{cccc}
\hline & 1987 & 1988 & 1989 \\
Germany & -1.88 & -43.80 & -4.60 \\
& & & \\
& 1974 & 1975 & 1976 \\
Canada & 1.808 & 4.394 & 8.772 \\
\hline
\end{tabular}

Source: IMF International Financial Statistics

This suggests that harmonization might lead to large and rapid portfolio shifts.

\section{Capital income taxation (foreign direct investment)}

This section qualifies the above analysis for capital flows associated with foreign direct investment rather than with financial investment. 


\section{Taxation and distortions}

For several reasons, the analysis of distortions induced by tax differentials is more complicated in the case of direct investment because many elements of the tax base are likely to diverge from country to country. Therefore, one cannot limit the analysis to divergences between tax rates.

\section{a. Theoretical background}

The analysis of tax neutrality must be qualified when direct investment is concerned.

The first qualification concerns the case of individuals investing in shares. A resident of one country (individual or legal person) can buy shares of a foreign company and a triple taxation of dividends can arise (corporate tax, source and residence based personal income taxes). International conventions do not always solve the problem since tax credit for corporation taxes is usually limited to domestic dividends.

The second qualification concerns corporations that have shares of a foreign company. In the limiting case of a parent and a subsidiary, the latter can finance itself in four ways: self financing, issue of debt, issue of shares, and issue of debt with the parent. In this situation, in order to achieve neutrality, one needs CEN, CIN, and absence of distortion in the cost of capital and investment financing. Three conditions for this are elaborated in Keen (1991). The first condition is the application of the residence principle, but must take into account the problem of deferral, i.e. the provision by which foreign source income is taxed in the residence country not upon its earning, but upon its repatriation. This makes the choice of investment depend upon the comparison between net returns, as under the source rule (Hartman, 1985) ${ }^{10}$.

10 Some countries (e.g. the USA) adopt the residence principle with a credit given for foreign taxes (limited to the home tax liability) and defer taxation on foreign source income until its repatriation. Then, if the foreign subsidiary has a dollar and intends to reinvest it abroad, simultaneous repatriation 
The second condition is that the definition of the tax base must consider: full deductibility of interest; coincidence between tax depreciation schedule and economic depreciation; and full tax credit for dividends with no discrimination between domestic and foreign ones. The third condition is equality between corporate tax rates.

Therefore, the achievement of tax neutrality requires the fulfillment of a higher number of conditions than in the case of portfolio investment and the need for some formal arrangement between countries seems to be even more necessary. Before drawing this conclusion, however, one must see how differences in taxation actually affect the decisions of economic agents in practice.

of profits and direct investment through funds transfer are inferior to the alternative of making no funds transfer, since the former results in an unnecessary tax payment to the home country. Hartman (1995) argues that one should differentiate between two types of foreign operations: the "new" ones, in which case the source of internal funds is a transfer from the parent, and the "mature" ones, in whick. case the source of funds is a reduction in dividends payments to the parent. In the situation in which investment is financed by capital transfers from the parent to the subsidiary, it can be shown that the effective tax rate on the operation is a weighted average of the home and foreign country tax rates, with the exact value depending on the timing of the deferred tax payment. Suppose, instead, that a foreign subsidiary has one dollar of after foreign tax earnings which it can either invest or repatriate to its parent. If the dollar is reinvested, the dollar plus the one period investment earnings will be repatriated at the end of the period. If the subsidiary repatriates, after investing for the period the parent has $(1-t)\left(1+r^{\prime}\right) /\left(1-t^{*}\right)$; wher $r$ is the net return available at home. If the subsidiary reinvests, at the end of the period the parent receives $(1-t)(1+r(1-t)) /\left(1-t^{*}\right)$. Therefore, the subsidiary reinvests if $r^{*}\left(1-t^{*}\right)>r^{\prime}$, which means that the domestic tax applied to foreign source income plays no role in the firm investment decision. In fact, since the potential foreign direct investment is to be financed out of foreign subsidiary earnings, which will currently or in the future bear the same home country tax liability, the only question for the firm is in which location those earnings could be invested to produce the highest net return. A tax increase would immediately lower the value to the parent firm of the future subsidiary earnings, but would do nothing to alter future decisions. Only for firms with immature foreign operations (i.e. requiring transfers from the parent) is the home country tax a deterrent to investment. Keen (1991) has questioned the Hartmann (1985) result (which is similar to that in Sinn, 1984) on the ground that it is based on the assumption of independent profitability, i.e. that local sales can only come from local production. Integration of goods markets, instead, establishes a direct link between the profits of a parent and a subsidiary producing the same good, since the common price at which they sell it will depend on the production conditions of both of them. Therefore, under a system of partial credit with deferral, a sufficiently large fall in the rate of corporation tax at home will always reduce the attractivness of retention financed investment for the mature subsidiary. Also, change in the form of double taxation relief will also affect the investment behaviour: a change to deduction without deferral would encourage investment at home while discouraging it abroad. 


\section{b. Empirical evidence}

There is not much empirical evidence on the cross-border effects of direct investment taxation. An OECD (1991) study uses a model developed by King and Fullerton (1984) and extended by Crooks, Devereaux, Pearson and Wookey (1989) to compute effective tax rates on transnational investment. This allows one to assess the degree of respect or violation of CEN and CIN (comparing the differential between effective tax rates faced by a firm investing in different countries or by firms of different residence investing in the same country). The study provides evidence of the existence of substantial differentials according to the country where investment is located or according to the residence of the firm undertaking the investment.

But the simple existence of these differentials does not imply that companies actually change their behavior because of it. However, some evidence in this direction can be found in the replies to a survey conducted on behalf of the Ruding Committee (1992) among EC and EFTA companies. As far as production plants are concerned, to the question "how often are taxes faced in alternative locations a factor in the decision in which country to locate investment?", $22 \%$ answered "always", $26 \%$ "usually", 33\% "sometimes" and 19\% "never"11. This gives some evidence of the absence of CEN. Further evidence is supplied by Devereaux and Pearson (1989) for withholding taxes levied by countries on profits if companies choose to send them out of the source country. They found that this kind of tax has a large distortionary impact relative to the amount of revenue they raise. Abolition of these taxes was estimated to bring a possible reduction of the distortions of the location of investment in the EC by up to one third. These are large numbers, which make the elimination of the distortion an important issue.

Another study referring to the European integration process is that by de la Fuente and Gardner (1990) (for the main stages in the EC corporate tax harmonization process, see Box 1). They compute the tax wedges between the pre-tax return to the company and the post tax return to a shareholder along the King and

11 The replies from firms located in important financial service centers showed a larger relevance of the tax factor: $52 \%$ answered "always", $26 \%$ "usually", 13\% "sometimes" and $9 \%$ "never". 
Fullerton (1984) model lines. They find relevant tax wedge differentials in the EC and show that corporate tax base harmonization would reduce them very significantly. However, the efficiency gains for the Community as a whole would be very modest. The effects for individual countries would instead be quite relevant. The larger winner would be Germany, with a $15 \%$ increase in its share of the EC capital stock, while the largest losers would be Ireland and Luxembourg, with a 17 and 15\% reduction in their shares respectively. As for the effects on the rest of the world, they derive from the fact that in their model the average tax wedge declines as a result of harmonization. Then, the demand for capital rises, and so does the interest rate. This forces a reallocation of capital from the USA and Japan toward the EC. 
Box 1. Corporate tax harmonization in the EU. The situation of the corporate tax in the EU, to take one example, is far from achieving the neutrality conditions elaborated in the literature. In that case, one problem of the harmonization process is that the aim of "international" neutrality is mixed up with that of the neutrality of the corporation tax itself. Limiting the analysis to the aspects that are not purely "national", the main interaction between the fiscal and the economic aspects is perhaps that concerning the double taxation of dividends. One can speak of a double taxation of dividends in two cases: a) with respect to the personal income tax, since dividends are taxed twice, first with the corporation tax, which hits the firm for its profits, and then with the personal income tax, which hits the shareholder for the dividends they receive; b) with respect to the corporation tax, since the dividends received by a corporation are included in its taxable income. In the first case, the double taxation can be reduced by adopting a lower corporate tax rate to distributed than to non distributed profits (split rate system); or by giving a tax credit to the shareholder (the credit is first summed to the dividend to compute the taxable income and then subtracted from the amount of the tax). If the integration of the personal and corporate taxes takes place at the corporate level by adoption of the split rate system, CIN would be easily reached through harmonization, even if there is the problem of finding the rate for profits distributed to a foreign parent by a subsidiary (Di Majo, 1992). If one chooses the shareholder level, the dividend exemption system is a problem because it cannot include a credit for non residents. In the case of a corporation taxed for the dividends it receives from another firm, there is an issue in the case of parent and subsidiary with residence in different countries, since the solution of the problem has not been reached at the Community level but through bilateral treaties, which can have important consequences on revenue distribution among countries. Moreover, there are treaties also with extra EC countries that induce a "treaty shopping effect" to exploit the fiscal opportunities deriving from them (in fact, this problem has arisen also within the EC - take Luxembourg, for example). The Directive 90/435 proposed two methods to cut the knot of bilateral treaties within the Community: a) Exemption. The country of the parent exempts the dividends that the corporation receives from the subsidiary; this method can lead to competition among capital importing countries; b) Imputation. The residence state taxes the dividends, allowing for a tax credit equal to the tax paid by the subsidiary; the subsidiary residence state does not apply any withholding tax on distributed dividends. This method can lead to revenue extraction: the country of residence of the subsidiary can increase its tax rate as it wishes since credit is integral. The Ruding Committee Report (1992) presented further proposals for the elimination of discriminatory features of the tax structure and the harmonization of the corporate tax base, plus the setting of a minimum $30 \%$ tax rate. 
In conclusion, there is some evidence of the existence of distortions deriving from differences in taxation; therefore, a higher degree of tax uniformity would be beneficial.

\section{Distortions and competition}

This question addresses the problem of whether competition between fiscal systems can lead to some desired degree of tax uniformity, or whether harmonization through formal agreements is necessary.

\section{a. Theoretical background}

As already mentioned, a country's choice of tax rate influences the decisions of other countries. Consider the case of a source-based corporate tax. To attract investment, countries could undercut each other. This could lead to zero tax rates and revenues, or to an equilibrium with positive tax rates and revenues, which is not optimal since countries do not internalize the reciprocal spillover effects.

In assessing the welfare loss deriving from the presence of this externality, one must consider that direct investment is less mobile and therefore less affected by tax rate differentials than portfolio investment. Moreover, countries might not engage in competition because of the presence of location specific profits, or because cutting tax rates and revenue from corporation taxes might require an increase of distortionary taxes on less mobile factors (see Appendix for a formal approach to these problems).

Also, a distinction should be made between physical capital and paper profits. Moving paper profits is easier than moving physical capital, in spite of rules on transfer pricing and thin capitalization. Moreover, differences in statutory tax rates are the basic tool to attract paper profits. Competition might then arise and push tax rates 
down. Therefore, some form of arrangement seems necessary to avoid a drop in tax rates and revenues to an undesirable level. In order to attract physical capital, instead, effective tax rates are important. These depend on all aspects of the tax structure; while competition might drive tax rates down, it is unlikely that it might equalize all other aspects of the tax structure. In this case, competition is unlikely to bring a desirable outcome, not so much because it would be too severe, but because it cannot eliminate all the distortionary features of taxation. In fact, while tax rate equalization can indeed be achieved through a competition process which pushes down the higher ones, fulfillment of the other conditions requires cooperation. Harmonization of the corporate tax along these lines, however, would take away the autonomy of the single countries. Alternatives have been indicated which would be compatible with some degree of flexibility 12 .

Moreover, one cannot draw conclusions on the need for coordination without having an idea of the relevance of externalities in practice. This is the topic of the next section.

12 Among these, the elimination of deferral and the change of the corporate tax base according to the Meade (1987) S-base cash flow logic (see Paladini, 1993). Elimination of deferral involves some problems. As for individuals, one should establish information flows on foreign earnings and then choose between the residence principle with the reimbursement to the non resident of the eventual source based tax on the one hand and full credit with reimbursement by the resident country on the other hand. The two criteria differ only in the distribution of revenue: capital exporting countries prefer the former, capital importing the latter. As for corporations, the problem is overcoming national sovereignty. In the case of a tax credit to an individual resident, the recognition of a foreign country tax right is already present. In the case of firms, the end of deferral means either that the country where the subsidiary is located gives up taxation of its earnings or that the parent's country gives full credit, recognizing the right of the other country. As for the cash flow based tax, this solution would be compatible with deferral. There should then be some rule to avoid thin capitalization (since passive interests are a deductible cost, while dividends are profits by which the subsidiary is taxed, it is convenient for the parent to give a credit to the subsidiary rather than increasing its capital) and full tax credit should be granted. However, the cash flow based tax has remained an academic proposal. The last solution is that of adopting a common tax base and parameters on the basis of which to decide how to redistribute revenues among different countries. All these solutions imply some form of cooperation. A completely different way of achieving efficiency is the "federal state" solution: this involves a common base and a criterion of distributing the intakes among countries on the basis of parameters such as the volume of sales, the wage bill, and the value of assets in each member state. The desired degree of integration with the individual income tax might then be left to the single country's choice. 


\section{b. Competition in practice}

The empirical study by de la Fuente and Gardner (1990) found that the greatest loser from the harmonization of corporate tax rates in the EC would be Ireland. In fact, this country has pursued a policy of attracting foreign direct investment by granting a very generous treatment to the profits of the manufacturing sector in the form of a $10 \%$ corporate tax rate (plus other subsidies). In fact, this low rate seems to have succeeded in attracting foreign companies: in 1983, for instance, the foreign companies' share of net output was $98.4 \%$ in office and data processing equipment, $98.1 \%$ in pharmaceuticals, $86.4 \%$ in electrical engineering, and $98.0 \%$ in industrial engineering. In 1987, foreign companies provided for $80 \%$ of non food manufactured exports (source: OECD, 1987). As a consequence of this generous tax treatment, revenues from corporate taxation have been low (see Table III; for a comparison, note that the OECD average ratio of corporate to total tax revenue was $8 \%$ in 1988).

\section{Table III}

\section{Corporate to total tax revenue ratio in Ireland}

\begin{tabular}{llllllllll}
\hline 1983 & 1984 & 1985 & 1986 & 1987 & 1988 & 1989 & 1990 & 1991 & 1992 \\
\hline 0.038 & 0.033 & 0.032 & 0.035 & 0.033 & 0.040 & 0.037 & 0.049 & 0.060 & 0.069 \\
\hline
\end{tabular}

Source: IMF Government Financial Statistics (1995) and author's calculations.

Therefore, undercutting has worked in attracting investment, but probably at the cost of lower revenues. This has caused a higher tax burden on personal income (see Table IV). 
Table IV

Personal income to total tax revenue ratio in Ireland

\begin{tabular}{llllllllll}
\hline 1983 & 1984 & 1985 & 1986 & 1987 & 1988 & 1989 & 1990 & 1991 & 1992 \\
\hline 0.266 & 0.282 & 0.284 & 0.303 & 0.322 & 0.335 & 0.309 & 0.307 & 0.309 & 0.304 \\
\hline
\end{tabular}

Source: IMF Government Financial Statistics (1995) and author's calculations.

The necessity of increasing distortionary taxes on other factors is one of the theoretical reasons why one cannot expect tax competition to be wild in the field of direct investment. Actually, the undercutting strategy of Ireland has not caused reactions from other European countries (in the period examined, the second lowest tax rate was $34 \%$ in the United Kingdom and in France). Therefore, one should not fear a "tax war" leading to zero rates and revenues in all integrating countries. This result, however, might well depend on the small dimension of Ireland with respect to the rest of the EC and on the fact that other EC countries, more developed than Ireland, were less concerned with attracting investment than with taxation equity. It can therefore be applied to situations where a less developed country makes a regional integration agreement with more developed ones (so called North-South agreements). How would arguments differ in the case of developing countries, all eager to attract foreign capital from the rest of the world, making regional integration agreements with each other (so called South-South agreements)? This question is addressed in the following section.

\section{Tax coordination and developing countries}

International interactions of tax systems are particularly important for developing countries since international mobility of factors may constrain the possibility of tax reform. This section analyses the principles that should guide taxation of income from foreign direct investment and the corresponding tax systems. It also provides an overview of some institutional arrangements existing at the regional level and argues that, in the case of the capital exporting countries granting a 
credit system, the kind of agreement needed to avoid competition in attracting foreign direct investment is a customs union.

\section{a. Principles of tax coordination}

On the assumption that capital inflow is an advantage for developing countries, three major areas of tax coordination have received attention in the literature (Gersowitz, 1987; Musgrave, 1987; Bird and Oldman, 1990; Tanzi, 1990; Boskin and McLure, 1990; Khalidazeh-Shirazi and Shah, 1991; for capital flights see Eaton and Gersowitz, 1984; Lessard and Williamson, 1987; Diaz, 1987; Shah and Slemrod, 1991; Fernandez-Arias and Spiegel, 1996).

The first area is the role of incentives. The most important thing to note is that it is the (developed) capital exporting country that controls incentives by choosing whether to exempt or to tax foreign source income. With a residence based tax, double taxation can be moderated by credit or deduction. With exemption or deferral, control on incentives is transferred to the source (capital importing country), which may then choose to apply a lower corporate rate than in the developed country and may thus attract capital.

The second topic is that of incentives to reinvestment. Tax arrangements introducing a differential in favor of reinvested earnings can strike a trade off between the need for revenue and that for capital inflow. It is necessary that the exporting country allows for exemption or deferral. In the case of exemption, developing countries may combine a low tax on profits with a high withholding tax on remitted earnings; also the system of tax credit with deferral induces reinvestment.

The third concern is protection against tax competition. With the residence country granting exemption, tax sparing (i.e. it credits the normal foreign source tax even if subsidies are granted to investors in the capital importing country) or deferral, developing countries are induced to compete with each other for foreign capital by 
lowering their tax rates. This involves a loss of revenue and should be avoided by coordination of tax and incentive policies.

The following section briefly describes how institutional arrangements have dealt with these problems.

\section{b. Institutional arrangements}

Apart from the polar cases of unilateral coordination and federation arrangements, there exist: 1) bilateral and multilateral treaties; 2) regional integration arrangements.

1) Tax treaties (Patrick, 1980). International tax treaties are addressed to: a) the assignment of specific taxes to countries of residence and source; $b$ ) the uniform definition of the tax base; $c$ ) the division of that base between countries of source in the case of multinational corporations owning plants that contibute to the same production process in different countries; d) the limitation of the tax rate in the country of source; e) the alleviation of double taxation burdens.

The OECD Model tax treaty (1963) and the UN Model treaty (1980) have proposed provisions for multilateral acceptance. Among the issues already mentioned, these models recognize the right to tax business profits and immovable property in the source country. As for the division among countries of source of the taxable profits of multinational corporations, the "separate accounting" method is now endorsed by both the OECD and the UN (income is assigned to divisions of firms in different countries by using traditional accounting methods and "arm length" prices). It should also be noted that tax administrations in most developing countries are poorly equipped to cope with transfer pricing issues. Some countries, especially in Latin America, have enacted simple rules, like minimum corporate taxes based on turnover, use of royalty fees based on the volume of natural resources extraction, and disallowance of deduction on equity infusions by foreign-based parents. 
As for the tax shares of foreign investment income claimed by the country of source, there are usually limitations to business income taxes, on the basis of the nondiscrimination principle, and to withholding taxes on dividends, on the basis of the reciprocity principle. In contrast to the OECD (1963) Model, the UN (1980) Model has sought to address some concerns expressed by developing countries (see various Reports of the UN group of experts between developed and developing countries). Examples of these concerns are: the request of the extension of the permanent establishment rule (article 5 of the OECD Model), constraints on the deductibility of intra-firm payments, and the reciprocity of withholding taxes.

2) Regional tax coordination among developing countries. Several attempts have been made to achieve some form of tax coordination (Table V), but only few have resulted in lasting arrangements (Salgado Penaherrera, 1980). 


\section{Table V.}

\section{Examples of Regional Integration Treaties}

\begin{tabular}{|c|c|c|}
\hline Regional treaties & $\begin{array}{l}\text { Year of } \\
\text { agreement }\end{array}$ & Main features (and source) \\
\hline $\begin{array}{l}\text { CACM } \\
\text { Central American Common } \\
\text { Market }\end{array}$ & 1958 & $\begin{array}{l}\text { Common market with a common external tariff and equalization of } \\
\text { indirect taxes; harmonization of investment incentives capital } \\
\text { income taxes. Uniform classification of industries eligible for tax } \\
\text { concessions (Gillim, 1967a). }\end{array}$ \\
\hline $\begin{array}{l}\text { LAFTA (later LAIA) } \\
\text { Latin America Free Trade } \\
\text { Association }\end{array}$ & $\begin{array}{l}1961 \\
(1980)\end{array}$ & $\begin{array}{l}\text { Prohibition of discriminatory treatment of trade and capital; no } \\
\text { common fiscal incentives policy; no elimination of double taxation } \\
\text { because of involved loss of national sovereignty; need for uniform } \\
\text { tax incentives was recognized, but not provided for (Gillim, } \\
\text { 1967b; and Organization of American States, 1980). }\end{array}$ \\
\hline $\begin{array}{l}\text { ANCOM } \\
\text { Andean Common Market } \\
\text { (later Andean Subregional } \\
\text { Integration Agreement) }\end{array}$ & 1969 & Prevention of double taxation of capital (Ffrench-Davis, 1976). \\
\hline $\begin{array}{l}\text { CARICON } \\
\text { Caribbean Community }\end{array}$ & 1973 & Harmonization of fiscal incentives (Musgrave, 1987). \\
\hline $\begin{array}{l}\text { EAC } \\
\text { East African Community }\end{array}$ & 1967 & Uniform corporate tax (Due and Robson, 1967) \\
\hline $\begin{array}{l}\text { UDEAC } \\
\text { Central African Custom and } \\
\text { Economic Union }\end{array}$ & 1966 & $\begin{array}{l}\text { Source based company taxation with apportionment system; } \\
\text { common code for investment (Due and Robson, 1967). }\end{array}$ \\
\hline $\begin{array}{l}\text { ECOWAS } \\
\text { Economic Community of } \\
\text { West Africa States } \\
\end{array}$ & 1977 & $\begin{array}{l}\text { Harmonization of industrial incentives and development plans; } \\
\text { compensation for losses from industry relocation (Musgrave, } \\
\text { 1987). }\end{array}$ \\
\hline $\begin{array}{l}\text { CAEU } \\
\text { Council of Arab Economic } \\
\text { Unity }\end{array}$ & 1961 & $\begin{array}{l}\text { Harmonization of income tax; assignment of specific taxes to } \\
\text { source and residence countries (Musgrave, 1987). }\end{array}$ \\
\hline
\end{tabular}


It has been argued that regional agreements entail a particular advantage in the case of developing countries: if they involve constancy and credibility in tax policy, they can provide a more stable environment for foreign direct investment (Burgess and Stern, 1993). But which kind of agreement is really necessary in the field of capital income taxation? The next section argues that, under certain conditions, a common external tariff toward the capital exporting countries is what is needed to avoid the negative effects of competition between tax systems.

\section{c. Competition to attract foreign direct investment}

As mentioned above, the taxation system chosen by the capital exporting country is what determines the incentives for competition in the capital importing ones. Consider a world with three countries: the home country and the partner country (the variables of which are denoted by an asterisk, *), which have a regional integration agreement, and the rest of the world (variables denoted by superscript "w"). If the rest of the world chooses to exempt its residents from taxation of income from capital invested abroad, capital will flow from the rest of the world to the home and the partner country if $\mathrm{r}^{\mathrm{w}}\left(1-\mathrm{t}_{\mathrm{r}}^{\mathrm{w}}\right)<\mathrm{r}\left(1-\mathrm{t}_{\mathrm{s}}\right), \mathrm{r}^{*}\left(1-\mathrm{t}_{\mathrm{s}}^{*}\right)$, where $\mathrm{r}$ is the interest rate, $t_{\mathrm{r}}$ a residence based tax and $t_{s}$ a source based tax. The exemption system gives an incentive to the capital importing countries to compete in lowering the tax rate to attract capital.

If the rest of the world chooses instead a credit system, then there will be no incentive for the capital importing countries to set $t_{s}$ and $t^{*}<t^{\mathrm{w}}{ }_{\mathrm{r}}$, since the burden on the foreign investor will still be $t^{\mathrm{w}}{ }_{\mathrm{r}}$. Therefore, they will set their tax rates equal to that in the capital exporting country. However, if the rest of the world allows for tax sparing, the latter can still compete raising the subsidies they concede.

If tax sparing is not allowed by the capital exporting country, the two developing countries cannot alter taxes and subsidies to attract foreign investment; however, they can use trade taxes, e.g. tariffs (see Corden, 1967) ${ }^{13}$. These will

${ }^{13}$ For the relationship between foreign direct investment and tariffs see Jones (1967); Caves (1967); Kemp (1969); Brecher (1983); Brecher and Findlay (1983); Bhagwati, Brecher, Dinopoulos and 
however be distortionary since they will alter the allocation of domestically owned resources and of consumption. One can then consider the game between two countries targeting capital inflow and imports (this derives from the Jones (1967) decomposition of changes in real income; see also Bond, 1991). For the home country, the capital inflow will depend positively on the differential between the tariff it imposes and the tariff imposed by the partner country; imports are instead negatively related to the tariff level (if the tariff is optimal except for the externality). If countries do not internalize the negative effect deriving from an increase in their own tariff on the inflow of capital to the other country, tariffs will be set too high. Under this perspective, a trade agreement like the establishment of a common external tariff seems all that is required for developing capital importing countries to avoid competition in attracting foreign direct investment, or, in other words, a customs union agreement ${ }^{14}$.

\section{Conclusions and directions for further research}

Cross country uniformity of taxes on income from mobile factors is not necessarily an optimal outcome because the tax rate around which equalization takes place might not be the "right" one. This is true both when this rate emerges from a competitive process and when it derives from a formal harmonization arrangement. With a competitive process, externalities impede the achievement of an optimal outcome. With formal harmonization, since taxation is used to achieve different objectives in different countries, uniformity would involve costs in terms of national preferences (moreover, there is no guarantee that the chosen common rate is the most efficient one).

Srinivasan (1987); Winters (1988); Bond (1991); Bhagwati, Dinopoulos and Wong (1992); Kim and Wilson (1996).

${ }^{14}$ For the issue of factor mobility and optimal tariffs see also Wooton (1988). Richardson (1993) shows that, if the external tariff is endogenous, a free trade area is preferrable to a customs union since trade diversion is lower under the former. The reason is that the external tariff will tend to be lower in a free trade agreement, since the country with a comparative disadvantage in a good (relative to its partner) will decrease protection against imports from the rest of the world. See also Grossman and Helpman (1995). This result should be confronted with the incentive to increase protection deriving from the desire of attracting foreign direct investment. 
However, given that what eventually matters in the context of regional integration is that countries do not exploit each other, the principle of uniformity can be abandoned for that of mutual recognition of taxation power, which allows countries to retain some degree of flexibility ${ }^{15}$. Consider, for instance, the following situation for the case of financial investment: the union countries apply the source principle; then, equilibrium conditions will yield:

$$
\begin{aligned}
& r\left(1-t_{r d}\right)=r^{*}\left(1-t^{*}{ }_{n d}\right) \\
& r^{*}\left(1-t^{*}{ }_{r d}\right)=r\left(1-t_{n d}\right),
\end{aligned}
$$

the non arbitrage conditions will yield:

$$
t_{r d}>,=,<t *_{n d} \text { for } r *<,=,>r \text { for } t^{*}{ }_{r d}<,=,>t_{n d} \text {. }
$$

If interest rates are the same in the two countries, $t_{r d}$ must equal $t^{*}$ nd (and symmetrically for the foreign country), i.e. the source based tax rate on non residents must equal their residence country tax rate on residents. Such a rule would allow the countries to set autonomously their tax rate, and at the same time eliminate cross border effects. Note also that if there are more than two countries in the union, the tax rates on non residents should discriminate according to the "internal" tax rates of the residence country. Then, source principle taxation is substantially very similar to residence principle taxation and one obtains CEN, not CIN (unless tax rates coincide). The main difference with the residence principle is that the latter allows for the taxation of capital income within the personal income tax. This has a practical importance only if the personal tax marginal rate is much greater than the source tax rate. Cooperation would allow governments to set rates high enough to make this issue unimportant. Financial investment taxation is however a field where some of the limits of regional integration clearly appear: if capital is mobile also between the integrating countries and the rest of the world, a more generous fiscal treatment in the rest of the world will attract capital away from the union. Therefore, in the absence of agreements with outside countries, regional tax coordination could be ineffective.

15 This principle also applies to the European environmental standards policy: after the failure of the negotiations for uniform standards in preparation to the 1992 internal market, the Commission shifted to the principle of "mutual recognition": according to it, lawful production and sale of goods in one member state implies free entrance into the markets of theother members. A comparable principle at the multilateral level is that of "reciprocity" (see Winters, 1990). 
The situation is somewhat different for less mobile factors. First, the constraint from the rest of the world will probably be less strong. Second, within the union the costs of moving factors will inhibit competition to bring the outcome of zero tax rates and revenues. This makes the case for centralized intervention less stringent.

Some conclusions can be drawn for regional integration agrrements involving developing countries. First, the administrative difficulties in copin - with "paper profit" taxation suggest the adoption of simple rules, like minimum corporate taxes based on turnover and disallowance of deduction on equity infusions by foreign based parents, to tackle "transfer pricing" problems. Second, the role of incentives to capital inflows and reinvestment is constrained by the taxation system chosen in the exporting country. The methods to avoid double taxation included in the OECD Model tax treaty - exemption in the residence country and tax credit - transfer the contol on incentives to the developing, capital importing country. Then, as in the examination of competition to attract foreign direct investment, it might be useful to distinguish between the case of South-South and North-South agreements. In SouthSouth agreements, the integrating countries will both be capital importing, and incentives to compete with each other to attract foreign direct investment might be very strong. However, the scope for tax competition depends on the taxation system adopted by the capital exporting countries. In the case of a credit system, integrating developing countries will compete by the use of tariffs rather than capital income taxes, and therefore the danger of competition can be avoided by the imposition of a common external tariff, with no need for particular agreements on capital income taxation. In the case of North-South arrangements, the North will be the capital exporting country and the South the capital importing one. In this situation it is possible that differences in the countries' preferences (and possibly the fact that the North accepts that the South attracts part of its tax base) mitigate strategic reactions.

Most of these issues cannot be appraised without further empirical investigation. In general, more research is needed to ascertain the mobility of productive capital. In the context of North-South regional agreements, it might be 
interesting to test how differences in preferences, size and other characteristics of the integrating countries influence the incentive for competition and the need for tax coordination. In the context of South-South regional agreements, one could look for evidence on the incidence of capital inflows on the choice of and deviations from common external tariffs and on the choice between a free trade area and a customs union agreement. 


\section{Appendix}

This appendix analyses the effects of factor income taxation and of the negative externality of the tax rate setting game in the presence of factor mobility ${ }^{16}$. It shows that, in the presence of migration costs and/or of a link between the tax rate on mobile and immobile factors, lack of coordination does not lead to a zero tax rate on mobile factors. It also argues that the welfare of both countries can be improved by imposing a minimum tax rate, but not by harmonization in the sense of the imposition of tax rate uniformity.

One can give a simple formal representation of the negative externality induced on the revenues of the other member countries by a partner's tax rate reduction aimed at attracting mobile factors.

Consider one country that wants to maximize its tax revenues (T). For simplicity, assume that the supply of the production factor is rigid and unaffected by taxation; that all factors produce the same constant income, normalized to unity; that the income tax is proportional, the rate $\mathrm{t}$ being the same for all income kinds ${ }^{17}$. $\mathrm{L}$ is the total supply of "immobile" factors and, given the assumptions made above, the total income they produce; $\mathrm{c}$ has the same meaning for "mobile" factors. An asterisk * denotes the corresponding variables of a second country (the other member of the union).

If $\mathrm{c}$ were immobile also, the revenue maximization problem:

$$
\max \mathrm{T}=\mathrm{t}(\mathrm{L}+\mathrm{c})
$$

$\mathbf{t}$

(where $\mathrm{T}$ is tax revenue, $\mathrm{t}$ is tax rate and $\mathrm{L}$ and $\mathrm{c}$ are the two factors)

implies that $\mathrm{t}$ is equal to $100 \%$, and similarly for the second country.

\footnotetext{
${ }^{16}$ For a more general analysis of the externalities produced by national fiscal policies see De Bonis (1996).

17 This is a simplyfing assumption, which is however justifiable on efficiency and equity grounds; moreover, at least in some cases, with different rates, the higher one could be eluded by a reclassification of income flows, e.g. from labour to capital income, if the rate on the latter is lower.
} 
Once borders are opened to the migratory flow of the production factors, if one assumes, again for the sake of simplicity, that gross income is the same in both countries and migration is costless, mobile factors will concentrate in the country with a lower tax rate. They can now be considered a unique entity, independently of the country of their original residence, and be denoted by $\mathrm{C}=\mathrm{c}+\mathrm{c}^{*}$.

The tax revenue is no longer a function of the country tax rate only, but also of the foreign one and problem (1) becomes:

$$
\begin{aligned}
& \max T\left(t, t^{*}\right)=t B \\
& \mathrm{t} \\
& \begin{array}{ll}
B=\quad L, & \text { if: } t \geq t^{*} \\
L+C, & \text { if: } t \leq t^{*},
\end{array}
\end{aligned}
$$

which implies:

$$
\begin{array}{lll}
T= & t L, & \text { if: } t \geq t^{*} \\
& t(L+C) & \text { if: } t \leq t^{*} .
\end{array}
$$

Each country will try to bring its tax rate below the foreign one. However, this will imply a reduction in revenues from the taxation of the immobile factors, which will be the more relevant, the larger $\mathrm{L}\left(\mathrm{L}^{*}\right)$ is with respect to $\mathrm{C}$. Therefore, the rate will never be reduced beyond the point at which the revenue from the immobile and mobile factors is lower than that can be obtained by taxing the immobile factors with a $100 \%$ rate, i. e.:

$$
t(C+L) \geq L
$$

This provides an explanation why, even with perfect international capital mobility, the capital income tax does not disappear, establishing a lower bound for $t$, beyond which the country will not go even at the cost of loosing the mobile factors: 


$$
\mathrm{t} \geq \mathrm{L} /(\mathrm{C}+\mathrm{L}) .
$$

Consequently, the choice of $t$ will be the following:

$$
\begin{aligned}
& t^{*} \leq \mathrm{L} /(\mathrm{C}+\mathrm{L}) \text { implies } \mathrm{t}=100 \% \\
& \mathrm{t}^{*} \geq \mathrm{L} /(\mathrm{C}+\mathrm{L}) \text { implies } \mathrm{t}<\mathrm{t}^{*}
\end{aligned}
$$

in the same way, for the second country:

$$
\begin{aligned}
& t \leq \mathrm{L}^{*} /\left(\mathrm{C}+\mathrm{L}^{*}\right) \text { implies } \mathrm{t}^{*}=100 \% \\
& \mathrm{t} \geq \mathrm{L}^{*} /\left(\mathrm{C}+\mathrm{L}^{*}\right) \text { implies } \mathrm{t}^{*}<\mathrm{t} .
\end{aligned}
$$

Graphically, assuming that when a country undercuts its partner's rate does this by 1 percentage point, equations (2) and (3), which are the reaction functions of the two countries, i. e. the optimal choice of $t\left(t^{*}\right)$ given $t^{*}(t)$, for $L<L^{*}$, can be represented as in fig. 1:

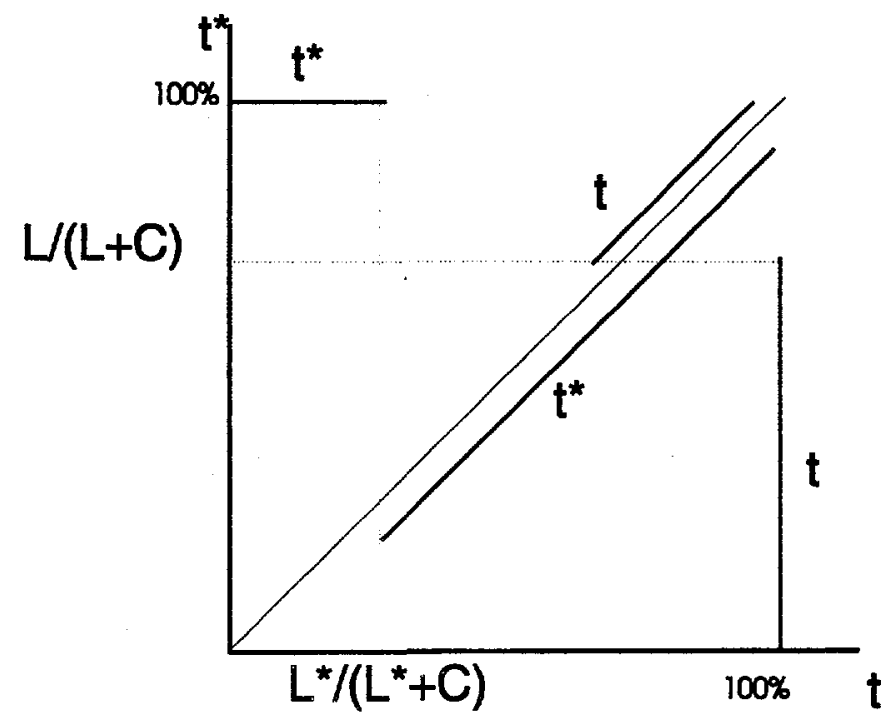

Fig. 1: The non existence of a competitive equilibrium. 
In this situation a non cooperative equilibrium does not exist. It would "degenerate" in the origin for $\mathrm{L}, \mathrm{L}^{*}=0$, with $\mathrm{t}=\mathrm{t}^{*}=0$; introducing a different degree of mobility through a different migration cost according to the factor type, so that not all mobile factors necessarily end up in the same country, one obtains a Nash equilibrium in which the rate on the mobile factor does not go to zero. Moreover, countries which are "small", in the sense that they have a lower endowment of factor, have an advantage in the competition process, their incentive in lowering the tax rate being greater, since what they possibly loose as a reduction of revenue from the immobile factors is more than compensated by the inflow of mobile factors (see the real example of capital fleeing from Germany to Luxembourg). In the cross-border shopping models, as in Kanbur e Keen (1993), the migration cost is given by the product of the unit distance cost $(\mathrm{k})$ and the distance between the consumer and the border (d). There are two countries which extend themselves along the interval $[-1,1]$, with the border at the origin. Population is uniformly distributed within both countries, so that those consumers for whom

$$
\left(\mathrm{t}-\mathrm{t}^{*}\right) / \mathrm{k}<\mathrm{d}
$$

shop abroad.

In the case being analyzed here, "distance" must be interpreted in terms of costs of transaction, activity restructuring, non perfect substitutability of capital across national borders or ownership structures, etc., according to the kind of factor.

The country revenue maximization problem then becomes:

$$
\begin{aligned}
& \max T\left(t, t^{*}\right)=t B \\
& \text { t } \\
& B=\quad\left(c-c\left(t-t^{*}\right) / k+L\right), \quad \text { if: } t \geq t^{*} \\
& \left(c+c^{*}\left(t^{*}-t\right) / k+L\right), \quad \text { if: } t \leq t^{*} \text {. }
\end{aligned}
$$


The solution to this problem is found by first considering the case of the country being constrained to choose a tax rate $t \geq t^{*}$, which yields:

$$
\begin{array}{ll}
t=(1 / 2)\left(k(c+L) / c+t^{*}\right), & \text { if: } t^{*} \leq k(c+L) / c \\
t=t^{*}, & \text { if: } t^{*} \geq k(c+L) / c .
\end{array}
$$

The revenues corresponding to these values are, respectively,

$$
\begin{aligned}
& \left.\mathrm{T}=\left(\mathrm{k}(\mathrm{c}+\mathrm{L}) / \mathrm{c}+\mathrm{t}^{*}\right) / 2\right)^{2}(\mathrm{c} / \mathrm{k}) \\
& \mathrm{T}=\mathrm{t}^{*}(\mathrm{c}+\mathrm{L})
\end{aligned}
$$

If the government is constrained to choose $t \leq t^{*}$, one gets

$$
\begin{array}{ll}
\mathrm{t}=\mathrm{t}^{*}, & \text { if: } \mathrm{t}^{*} \leq \mathrm{k}(\mathrm{c}+\mathrm{L}) / \mathrm{c}^{*} \\
\mathrm{t}=(1 / 2)\left(\mathrm{k}(\mathrm{c}+\mathrm{L}) / \mathrm{c}^{*}+\mathrm{t}^{*}\right), & \text { if: } \mathrm{t}^{*} \geq \mathrm{k}(\mathrm{c}+\mathrm{L}) / \mathrm{c}^{*}
\end{array}
$$

and therefore

$$
\begin{aligned}
& T=t^{*}(c+L) \\
& \left.T=\left(k(c+L) / c^{*}+t^{*}\right) / 2\right)^{2}\left(c^{*} / k\right) .
\end{aligned}
$$

One finds the optimal reply of the country as for the choice of $t$ by comparing the values of $T$ for the corresponding values of $t^{*}$.

For $t^{*} \leq \min \left[k(c+L) / c, k(c+L) / c^{*}\right]$, the maximum value of $T$ is obtained for $t\left(>t^{*}\right)$ $=(1 / 2)\left(\mathrm{k}(\mathrm{c}+\mathrm{L}) / \mathrm{c}+\mathrm{t}^{*}\right)$.

For $t^{*} \geq \max \left[k(c+L) / c, k(c+L) / c^{*}\right]$, the maximum value of $T$ is obtained for $t\left(<t^{*}\right)$ $=(1 / 2)\left(k(c+L) / c^{*}+t^{*}\right)$.

If $c^{*}<c$, for $k(c+L) / c \leq t^{*} \leq k(c+L) / c^{*}$, one gets $t=t^{*}$. 
If $c^{*}>c$, then for $k(c+L) / c^{*} \leq t^{*} \leq k(c+L) / c$, one gets that, for $k(c+L) / c^{*} \leq t^{*} \leq$ $\mathrm{k}(\mathrm{c}+\mathrm{L}) / \sqrt{c c^{*}}$, then $\mathrm{t}$ is $\left(<\mathrm{t}^{*}\right)=(1 / 2)\left(\mathrm{k}(\mathrm{c}+\mathrm{L}) / \mathrm{c}^{*}+\mathrm{t}^{*}\right)$; for $\mathrm{k}(\mathrm{c}+\mathrm{L}) / \sqrt{c c^{*}} \leq \mathrm{t}^{*} \leq \mathrm{k}(\mathrm{c}+\mathrm{L}) / \mathrm{c}$, then $t\left(<t^{*}\right)=(1 / 2)\left(k(c+L) / c^{*}+t^{*}\right)$.

Putting these results together, one obtains the solution to the revenue maximization problem, given the foreign tax rate (i. e. the reaction function of the country): for $c>c^{*}$,

$$
\begin{aligned}
& t\left(t^{*}\right)=(1 / 2)\left(k(c+L) / c+t^{*}\right), \quad t^{*} \leq k(c+L) / c \\
& \mathrm{t}^{*}, \quad \mathrm{k}(\mathrm{c}+\mathrm{L}) / \mathrm{c} \leq \mathrm{t}^{*} \leq \mathrm{k}(\mathrm{c}+\mathrm{L}) / \mathrm{c}^{*} \\
& (1 / 2)\left(k(c+L) / c^{*}+t^{*}\right), t^{*} \geq k(c+L) / c^{*} \text {; } \\
& \text { for } c<c^{*} \text {, instead, } \\
& \mathrm{t}\left(\mathrm{t}^{*}\right)=(1 / 2)\left(\mathrm{k}(\mathrm{c}+\mathrm{L}) / \mathrm{c}+\mathrm{t}^{*}\right), \quad \mathrm{t}^{*} \leq \mathrm{k}(\mathrm{c}+\mathrm{L}) / \sqrt{c c^{*}} \\
& (1 / 2)\left(\mathrm{k}(\mathrm{c}+\mathrm{L}) / \mathrm{c}^{*}+\mathrm{t}^{*}\right), \mathrm{t}^{*} \geq \mathrm{k}(\mathrm{c}+\mathrm{L}) / \sqrt{c c^{*}} \text {; }
\end{aligned}
$$

and symmetrically for the other country. Note that, given the link between the mobile and the immobile factor taxation and the presence of costs, at the competitive equilibrium the tax rate does not go to zero.

In the case of the foreign country being relatively "big" in terms of the endowment of mobile, i. e. $c^{*}>c$, and immobile, i. e. $L^{*}>L$, factors, then its tax rate will be higher than in the home country at the Nash equilibrium position. If this were not true, $i$. e. for $t^{*}<t$, the equilibrium values of $t$ and $t^{*}$ would be found by solving the system of equations (10) e (11):

$$
\begin{aligned}
& t^{*}=(1 / 2)\left(k\left(c^{*}+L^{*}\right) / c+t\right) \\
& t=(1 / 2)\left(k(c+L) / c+t^{*}\right)
\end{aligned}
$$

which implies

$$
t=(k / c)\left(2 / 3(c+L)+1 / 3\left(c^{*}+L^{*}\right)\right.
$$


i. e. $t<k\left(c^{*}+L^{*}\right) / c$, which contradicts the condition by which $t^{*}<t$ in the non cooperative equilibrium.

For $t^{*}>t$, the Nash solution is found by solving the system of equations (13) and (14):

$$
\begin{aligned}
& t^{*}=1 / 2\left(k\left(c^{*}+L^{*}\right) / c^{*}+t\right) \\
& t=(1 / 2)\left(k(c+L) / c^{*}+t^{*}\right)
\end{aligned}
$$

i. e.:

$$
\begin{aligned}
& \mathrm{t}=\left(\mathrm{k} / \mathrm{c}^{*}\right)\left(2 / 3(\mathrm{c}+\mathrm{L})+1 / 3\left(\mathrm{c}^{*}+\mathrm{L}^{*}\right)\right) \\
& \mathrm{t}^{*}=\left(\mathrm{k} / \mathrm{c}^{*}\right)\left(2 / 3\left(\mathrm{c}^{*}+\mathrm{L}^{*}\right)+1 / 3(\mathrm{c}+\mathrm{L})\right) .
\end{aligned}
$$

If the two countries are equal to each other, one obtains $t=t^{*}=(k / c)(c+L)$. These results, illustrated in Fig. 2 , are obtained also if $L$ is greater than $L^{*}$ but smaller than $\left(L^{*}+c^{*}-\right.$ c). Above this value, instead, the revenue loss from the immobile factors is not compensated by the increase deriving from the mobile ones for $t$ smaller than $t^{*}$.

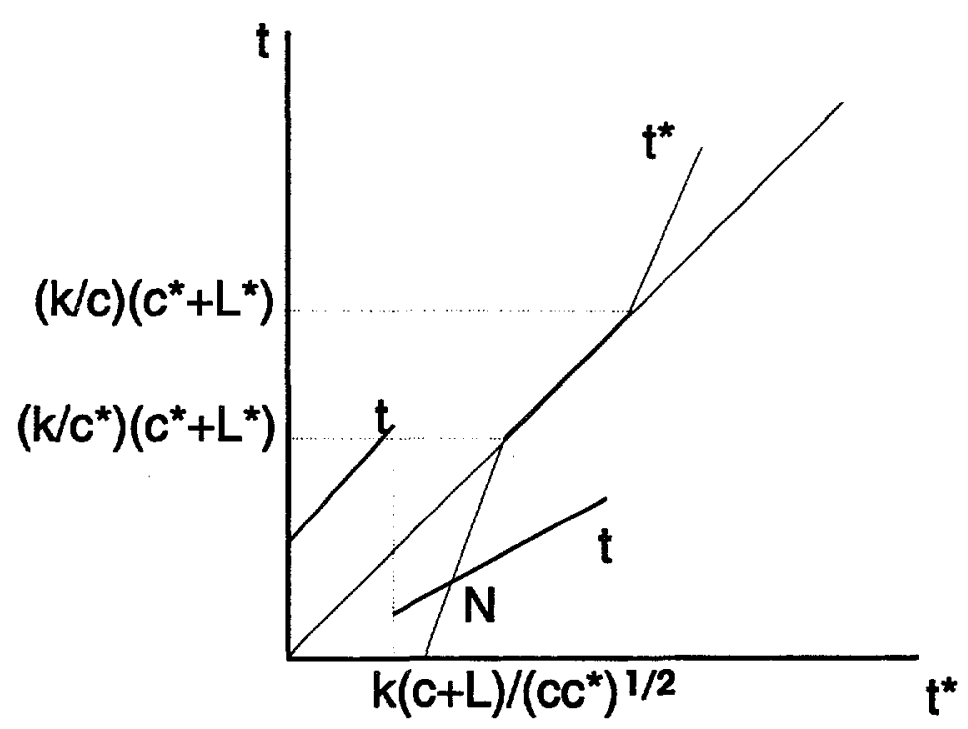

Fig. 2: The Nash equilibrium with the small country undercutting the big one $\left(t<t^{*}\right)$. 
With different tax rates for the immobile and the mobile factor, revenue maximization takes place separately for each of them. Therefore, the tax rate on the immobile factor will be $100 \%$ in both countries; the tax rate on the mobile factor will be the same as above, the only difference being that $\mathrm{L}$ does not appear in the maximization problem and its solutions. In the set up of this model, harmonization would harm the small country if it entails a common tax rate between the values chosen by the two countries in the Nash equilibrium. One can improve the situation of both countries only by allowing their tax rates to diverge. The way to do this is imposing a minimum rate such that, for the small country, the loss in revenue due to the decrease in the differential between $t$ and $t *$ is more than offset by the increase in revenue due to a higher tax rate ${ }^{18}$.

${ }^{18}$ For this result in commodity taxation see Kanbur and Keen (1993). 


\section{Bibliography}

Bhagwati, J.N., R.A. Brecher, E. Dinopoulos and T.N. Srinivasan (1987); "Quid pro quo foreign investment and welfare", in: Journal of Development Economics, 27: $127-138$.

Bhagwati, J.N., E. Dinopoulos and K. Wong (1992); “Quid pro quo foreign investment”, in: American Economic Review, Papers and Proceedings, 82: 186-190.

Bird, R. M. and O. Oldman (1990); Taxation in developing countries, Johns Hopkins University Press, Baltimore-London.

Bewley, T. F. (1981); "A critique of Tiebout's theory of local public expenditure", in Econometrica, 49: 713-740.

Bond, E. (1991); "Optimal tax and tariff policies with tax credit", in: Journal of International Economics, 30: 317-329.

Bond, E. W. and L. Samuelson (1989); "Strategic behavior and the rules for international taxation of capital", in Economic Journal, 99: 1099-111.

Boskin, M. J. and C. E. McLure (1990); World tax reform, International Center for Economic Growth, San Fransico (Calif.).

Brecher, R.A. (1983); "Second best policy for international trade and investment", in: Journal of International Economics, 14: 313-320.

Brecher, R.A. and R. Findlay (1983); "Tariffs, foreign capital and nation welfare with sectorspecific factors", in: Journal of International Economics, 14: 277-288.

Burgess, R. and N. Stern (1993); "Taxation and development", in Journal of Economic Literature, 31: 762-783.

Caves, R. E. (1982); Multinational enterprise and economic analysis, Cambridge University Press, New York.

Cnossen, S. (1990); "The case for tax diversity in the European Community", in European Economic Review, 34: 471-479.

Coase, R. (1960); "A theory of social costs", in: Journal of Law and Economics, 3: 1-44.

Corden, W. M. (1967); "Protection and foreign investment", in Economic Record, 43: 209233.

Crooks, E., M. Devereaux, M. Pearson and C. Wookey (1989); Transnational taxation and incentives to invest, IFS Working Paper 89/9, Institute for Fiscal Studies, London.

De Bonis, V. (1996); Esternalità negative delle politiche fiscali nazionali della spesa pubblica e dell'imposizione dei redditi", in: Problemi di Finanza Pubblica, 9: 2547. 
De la Fuente, A. And E. Gardner (1990); Corporate income harmonization and capital allocation in the European Community, IMF Working Paper 90/103, International Monetary Fund, Washington, D.C.

Devereaux, M. and M. Pearson (1989); Corporate tax harmonization and economic efficiency, IFS Report Series No. 35, Institute for Fiscal Studies, London.

Devereaux, M. and M. Pearson (1990); "Harmonizing corporate tax in Europe", in Fiscal studies, 11: 21-35.

Diaz, F. G. (1987); "Some lessons from Mexico's tax reform", in D. Newberry and N. Stern (eds); The theory of taxation for developing countries, World Bank, Washington, D.C.

Di Majo, A. (1992); 'L'armonizzazione delle imposte sulle societa' in Europa: aspetti istituzionali e di politica tributaria", in Bollettino della Associazione nazionale fra le Banche Popolari, N. 11/12: 7-72.

Due, J. and F. Robson (1967); "Tax harmonization in the East African Common Market", in C. Shoup (ed), Fiscal harmonization in common markets, Columbia University Press, London-New York.

Eaton, J. and M. Gersowitz (1984); "A theory of expropriation and deviation from perfect capital mobility", in Economic Journal, 94: 16-40.

Feldstein, M. and D. Hartman (1979); "The optimal taxation of foreign source investment income", in Quarterly Journal of Economics, 93: 613-630.

Fernandez-Arias, E. and M. M. Spiegel (1996); North-South customs unions and international capital mobility, Policy research working paper 1573, World Bank, Washington, D.C.

Ffrench-Davis, R. (1976); The Andean Pact: a model of economic integration for developing countries, Boston University Center for Latin American Development Working Paper 23.

Findlay, C. C. (1986); "Optimal taxation of international income flows", in Economic Record, 62: 208-314.

Frenkel, J.A., A. Razin and E. Sadka (1991); International taxation in an integrated world, MIT Press, Cambridge (Mass.).

Gersowitz, M. (1987); "The effects of domestic taxes on foreign private investment", in D. Newberry and N. Stern (eds); The theory of taxation for developing countries, World Bank, Washington, D.C.

Gillim, M. H. (1967a); "The fiscal aspects of the Central American Common Market", in C. Shoup (ed), Fiscal harmonization in common markets, Columbia University Press, London-New York.

Gillim, M. H. (1967b); "Some fiscal aspects of the Latin American Free Trade Association", in C. Shoup (ed), Fiscal harmonization in common markets, Columbia University Press, London-New York. 
Giovannini, A. (1989); "National tax systems versus the European capital market", in Economic policy, 9: 346-386.

Gordon, R. H. (1983); "An optimal taxation approach to fiscal federalism", in Quarterly Journal of Economics, 98: 567-586.

Grossman, G.M. and E. Helpman (1995); "The politics of free trade agreements", in: American Economic Review, 85: 667-690.

Hamada, K. (1966); "Strategic aspects of taxation on foreign investment income", in Quarterly Journal of Economics, 80: 361-375.

Hartman, D. G. (1985); "Tax policy and foreign direct investment", in Journal of Public Economics, 26: 107-122.

Horst, T. (1980); "A note on the optimal taxation of international investment income", in Quarterly Journal of Economics, 94: 793-799.

IMF (1991); International Financial Statistics Yearbook, International Monetary Fund, Washington, D.C.

IMF (1995); Government Financial Statistics Yearbook, International Monetary Fund, Washington, D.C.

Jones, R.W. (1967); "International capital movements and the theory of tariffs and trade", in: Quarterly Journal of Economics, 81: 1-38.

Kanbur, R. and M. Keen (1993); "Jeux sans frontie'res: tax competition and tax coordination when countries differ in size", in American Economic Review, 83: 877-892.

Keen, M. (1991); "Corporation tax and foreign direct investment", in L. A. Winters and A. J. Venables (eds); European integration: trade and industry, Cambridge University Press, Cambridge.

Kemp, M.C. (1969); The pure theory of international trade and investment, Prentice-Hall, Englewood Cliffs, New Jersey.

Khalizadeh-Shirazi, J. and A. Shah (1991); Tax policy in developing countries, World Bank, Washington, D.C.

Kim, J. And J.D. Wilson (1996); Capital mobility and environmental standards: racing to the bottom with multiple tax instruments, New York University Working Paper No. 195.

King, M.A. and Fullerton D. (1984); The taxation of income from capital: a comparative study of the United States, the United Kingdom, Sweden and West Germany, University of Chicago Press, Chicago.

Lessard, D. R. and J. Williamson (1987); Capital flight and third world debt, Institute for International Economics, Washington, D.C.

Markusen, J. R. (1983); "Factor movements and commodity trade as complements", in Journal of International Economics, 14: 341-356. 
Meade, J. E. (1978); The structure and reform of direct taxation, Allen and Unwin, London.

Mundell, R.A. (1957); "International trade and factor mobility", in: American Economic Review, 47: 321-335.

Musgrave, P. B. (1987); Coordination of taxes on capital income in developing countries, World Bank, Washington, D.C.

Musgrave, R. A. (1983); "Who should tax, where and what", in C. E. McLure (ed), Tax assignment in federal countries, Centre for Research on Federal Financial Relations, Canberra.

OECD (1963); Model tax treaty, OECD, Paris.

OECD (1987); OECD Economic Surveys: Ireland, OECD, Paris.

OECD (1991); Taxing profits in a global economy: domestic and international issues, OECD, Paris.

Organization of American States (1980); Inter-American Treaties and Conventions, OAS.

Paladini, R. (1993); "L'imposizione diretta nel processo di unificazione europea", in S. Micossi e I. Visco (eds); Inflazione, concorrenza e sviluppo, Il Mulino, Bologna.

Patrick, R. (1980); "US tax treaties with developing countries", in R. Hellawell (ed), United taxation and developing countries, Columbia University Press, New York.

Razin, A. and E. Sadka (1989); Optimal incentives to domestic investment in the presence of capital flights, Working paper 89/79, International Monetary Fund, Washington, D.C.

Richardson, M. (1993); "Endogenous protection and trade diversion", in: Journal of International Economics, 34: 309-324.

Ruding Committee (1992); Report of the Committee of independent experts on Company taxation, Commission of the European Communities, Brussels.

Salgado Penaherrera, C. (1980); "Viable integration and economic cooperation problems of the developing world", in Journal of Common Market Studies.

Schiff, M. (1994); How trade, aid, and remittances affect international migration, Policy research working paper 1376, World Bank, Washington, D.C.

Shah, A. and J. Slemrod (1991); "Taxation and foreign direct investment", in J. KhalizadehShirazi and A. Shah (eds); Tax policy in developing countries, World Bank, Washington, D.C.

Shaw, K. (1990); Fiscal harmonization in the European Community: the challenge of the single market, mimeo.

Sinn, H.-W. (1984); "Die Bedeutung des Accelerated Cost Recovery System fuer den internationalen Kapitalverkehr" in Kyklos, 37: 542-576.

Sorensen, P. B. (1989); On the welfare gains from international fiscal coordination, mimeo. 
Tanzi, V. (1990); Fiscal policy in open developing economies, International Monetary Fund, Washington, D.C.

Tanzi, V. and L. Bovenberg (1990); Is there a need for harmonizing capital income within EC countries?, Working paper 90/17, International Monetary Fund, Washington, D.C.

United Nations (1969-1980); Reports of the UN Group of Experts on tax treaties between developed and developing countries, UNO, New York.

United Nations (1980); Model tax treaty, UNO, New York.

Wellisch, D. and D. E. Wildasin (1996); "Decentralized income redistribution and immigration", in: European Economic Review, 40: 187-217.

Wildasin, D. E. (1994); "Income redistribution and migration", in: Canadian Journal of Economics, 27: 637-656.

Wildasin, D. E. (1995a); "Factor mobility, risk and redistribution in the welfare state", in: Scandinavian Journal of Economics, 97: 527-546.

Winters, L.A. (1990); "The road to Uruguay", in: Economic Journal, 100: 1288-1303.

Wildasin, D. E. (1995b); "Income distribution and redistribution within federations", forthcoming in: Annales d'Economie et de Statistique.

Wooton, I. (1988); "Towards a common market: factor mobility in a customs union", in: Canadian Journal of Economics, 21: 525-538. 


\section{Policy Research Working Paper Series}

Title

WPS1828 The Determinants of Banking Crises: Evidence from Developed and Developing Countries

WPS1829 Economic Reform and progress in Latin America and the Caribbean

WPS1830 Private Ownership and Corporate Performance: Some Lessons from Transition Economies

WPS1831 How Trade Patterns and Technology Wolfgang Keller Flows Affect Productivity Growth

WPS1832 Pension Reform in Bolivia: Innovative Hermann von Gersdorff Solutions to Common Problems

WPS1833 Cost Recovery and Pricing of Payment Services

WPS1834 The Comparative Advantage of Government: A Review

Norman Loayza

Luisa Palacios

Roman Frydman

Cheryl W. Gray

Marek Hessel

Andrzej Rapaczynski

David B. Humphrey

Robert H. Keppler

Fernando Montes-Negret

Pedro Belli

WPS1835 Cost-Benefit Anaiysis of the Global Aehyung Kim
Dracunculiasis Eradication Campaign Ajay Tandon

Ernesto Ruiz-Tiben

WPS1836 Health and Labor Productivity: The Economic Impact of Onchocercal Skin Disease

WPS1837 How Estonia's Economic Transition Affected Employment and Wages (1989-95)
Aehyung Kim

Ajay Tandon

Asrat Hairu and Others

Rivo Noorkoiv

Peter F. Orazem

Allan Puur

Milan Vodopivec
WPS1839 The Effects of Financial Liberalization Cevdet Denizer and New Bank Entry on Market Structure and Competition in Turkey

WPS1840 Efficient Public Sector Downsizing Martin Rama

WPS1841 Paiterns of Metropolitan Development: What Have We Learned?
October 1997

October 1997

Date

September 1997

September 1997

September 1997

September 1997

September 1997

October 1997

\author{
October 1907
}

October 1997

October 1997

S. Fallon 38009

October 1997

November 1997

Contact

for paper

P. Sintim-Aboagye 38526

E. Khine

37471

B. Moore 38526

J. Ngaine

37947

C. Pavlak 82099

T. Ishibe 38968

L. Schunk 31779

A. $\mathrm{Kim}$ 35029

A. $\mathrm{Kim}$ 35029

E. Thomas 31019

E. Khine 37471

November 1997

S. Fallon 38009

November 1997 J. Ponchamni 31052 
Policy Research Working Paper Series

Title

WPS1842 Motorization and the Provision of Roads in Countries and Cities

WPS1843 Externalities and Bailouts: Hard and Soft Budget Constraints in Intergovernmental Fiscal Relations

WPS1844 Child Labor and Schooling in Ghana

WPS1845 Employment, Labor Markets, and Poverty in Ghana: A Study of Changes during Economic Decline and Recovery

WPS1846 Africa's Role in Multilateral Trade Negotiations

WPS1847 Outsiders and Regional Trade Anju Gupta Agreements among Small Countries: Maurice Schiff The Case of Regional Markets

WPS1848 Regional Integration and Commodity Valeria De Bonis

Tax Harmonization

Author

Zhi Liu Dipak Mazumdar

Zhen Kun Wang

L. Alan Winters
Gregory K. Ingram

David E. Wildasin

Sudharshan Canagarajah Harola Coulombe

Sudharshan Canagarajah November 1997
Date

November 1997

Contact

for paper

J. Ponchamni 31052

November 1997

C. Bernardo 37699

B. Casely-Hayford 34672

B. Casely-Hayford 34672

November 1997

J. Ngaine 37947

November 1997

J. Ngaine 37947

November 1997

J. Ngaine 37947 